\title{
New insight into the contributions of thermogenic processes and biogenic sources to the generation of organic compounds in hydrothermal fluids
}

\author{
C. Konn ${ }^{1,{ }^{*}}$, D. Testemale ${ }^{2}$, J. Querellou ${ }^{3}$, N. G. Holm ${ }^{4}$, J. L. Charlou ${ }^{1}$ \\ ${ }^{1}$ Département Geosciences Marines, Ifremer CBrest, Plouzané, France \\ ${ }^{2}$ DépartementMCMF, Institut Néel, Grenoble, France \\ ${ }^{3}$ UMR6197 LM2E, Ifremer C/ Brest, Plouzané, France \\ ${ }^{4}$ Department of Geosciences, Geochemistry Section, Stockholm University, Stockholm, Sweden \\ *: Corresponding author : C. Konn. Tel.: +33 (0)298 224 264; fax: +33 (0)298 224 570; email address : \\ cecile.konn@ifremer.fr
}

\begin{abstract}
:
Experiments on hydrothermal degradation of Pyrococcus abyssi biomass were conducted at elevated pressure (40 MPa) over a $200-450^{\circ} \mathrm{C}$ temperature range in sapphire reaction cells. Few organic compounds could be detected in the $200^{\circ} \mathrm{C}$ experiment. This lack was attributed to an incomplete degradation of $P$. abyssi cells. On the contrary, a wide range of soluble organic molecules were generated at temperatures $\geq 350{ }^{\circ} \mathrm{C}$ including toluene, styrene, $\mathrm{C}_{8}-\mathrm{C}_{16}$ alkyl-benzenes, naphthalene, $\mathrm{C}_{11}-\mathrm{C}_{16}$ alkyl-naphthalenes, even carbon number $\mathrm{C}_{12}-\mathrm{C}_{18}$ polycyclic aromatic hydrocarbons, $\mathrm{C}_{15}-\mathrm{C}_{18}$ alkyl-phenanthrenes and $\mathrm{C}_{8: 0}-\mathrm{C}_{16: 0} \mathrm{n}$-carboxylic acids. The effect of time on the final organic composition of the degraded $P$. abyssi solutions at $350{ }^{\circ} \mathrm{C}$ was also investigated. For that purpose the biomass was exposed for $10,20,60,90,270$ and $720 \mathrm{~min}$ at $350^{\circ} \mathrm{C}$. We observed a similar effect of temperature and time on the chemical diversity obtained. In addition, temperature and time increased the degree of alkylation of alkyl-benzenes. This study offers additional evidence that a portion of the aliphatic hydrocarbons present in the fluids from the Rainbow ultramafic-hosted hydrothermal field may be abiogenic whereas a portion of the aromatic hydrocarbons and n-carboxylic acids may have a biogenic origin. We suggest that aromatic hydrocarbons and linear fatty acids at the Rainbow site may be derived directly from thermogenic alteration of material from the sub-seafloor biosphere. Yet we infer that the formation and dissolution of carboxylic acids in hydrothermal fluids may be controlled by other processes than in our experiments.
\end{abstract}




\section{Introduction}

Abiotic production of hydrocarbons in the Earth's crust was first postulated in the 1940s by Russian and Ukrainian scientists and is currently attracting great interest both in research and industry. Since their discovery in the late 1970s, Mid-Ocean Ridge hydrothermal systems have been regarded as favourable sites for abiotic synthesis of hydrocarbons and other organic compounds (Ingmanson \& Dowler, 1977) which may have provided material for the formation of prebiotic molecules (Ferris, 1992) and for the emergence of life on early Earth (Macleod et al., 1994). Thermodynamic calculations (e.g. Shock, 1990) and laboratory experiments (e.g. McCollom et al., 1999) have developed supporting lines of evidence of the feasibility of abiotic organic synthesis under hydrothermal conditions.

The geochemistry of hydrothermal fluids will differ depending on the host rocks being either basaltic (mafic) or mantle (ultramafic) derived. In the case of ultramafic-hosted systems, hydrothermal circulation, which leads to mineral alteration, takes place in the deep mantle peridotite intrusion into the ocean crust. Alteration of peridotites by seawater can be described by several chemical equilibria lumped together under the general term 'serpentinisation' (Frost \& Beard, 2007). Of particular interest is that serpentinisation reactions produce large amounts of molecular hydrogen $\left(\mathrm{H}_{2}\right)$ (Moody, 1976; Neal \& Stanger, 1983; Mevel, 2003). The concentration of $\mathrm{H}_{2}$ in ultramafic-hosted hydrothermal fields reaches $10-26 \mathrm{mM}$ which creates highly reducing conditions (Charlou et al., InPress). Thermodynamic calculations suggest that abiotic organic synthesis would particularly be favoured in these highly reducing environments (Shock, 1990; Macleod et al., 1994). Consistently high concentrations of abiogenic methane $\left(\mathrm{CH}_{4}\right)$, as well as other low molecular weight hydrocarbons $\left(\mathrm{C}_{2}-\mathrm{C}_{4}\right)$, have been reported in fluids from ultramafic- 
hosted hydrothermal systems (Proskurowski et al., 2008; Charlou et al., InPress). Catalytic processes such as the Sabatier reaction and Fischer-Tropsch Type (FTT) reactions have been suggested as potential reaction pathways for the formation of hydrocarbon gases in ultramafichosted hydrothermal systems and in many other geological settings (Sherwood-Lollar et al., 2002; Potter et al., 2004; Fiebig et al., 2007). However, the origin of higher molecular weight organic molecules observed in fluids from ultramafic-hosted hydrothermal vents remains unclear (Konn et al., 2009). On the one hand, FTT reactions can generate longer abiogenic n-alkanes via insertion of inorganic carbon, which in turn could serve as precursor for abiotic synthesis of various semivolatile and nonvolatile organic compounds. On the other hand, some of the organic compounds detected in ultramafic-hosted hydrothermal fluids may have a biogenic origin (Konn et al., 2009).

The sub-seafloor biosphere is the largest prokaryotic habitat on Earth (Whitman et al., 1998; Parkes et al., 2005). Despite the limited information available on its distribution and composition at global scales, diverse population of prokaryotes have been observed in several case studies (Cowen et al., 2003; Takai et al., 2004; Huber et al., 2006; Fry et al., 2008; Takai et al., 2008). The sub-seafloor biosphere extends down at least to 1626 meter below sea floor (Roussel et al., 2008) and constitutes a potential organic carbon reservoir for chemical reactions. In ocean ridges context, hydrothermal circulation could thermally degrade part of this biosphere, resulting in the release of organic compounds in hydrothermal fluids. Additional thermogenic or abiogenic processes may use these biogenic compounds to generate other organic compounds. Hydrothermal reaction processes may utilise both abiogenic $\left(\mathrm{CO}_{2}\right.$, mantle $\left.\mathrm{C}\right)$ and biogenic (e.g. degradation products of microorganisms, $\mathrm{CH}_{4}$ from methanogens) carbon sources and produce organic compounds from mixed carbon sources. The terminology for these compounds has not yet been defined. Organic compounds that can be called abiogenic should result from chemical 
reactions that have not been biologically catalysed and be composed solely of carbon of abiogenic origin. Assessing whether thermogenic alteration processes prevail or to what extent they compete with abiogenic processes is crucial for the overall understanding of hydrothermal systems as well as their potential role in the abiotic organic synthesis and thus in the origin of life.

Although compound specific carbon stable isotope measurements have been used for discrimination between biogenic and abiogenic origin of simple molecules like $\mathrm{CH}_{4}$, individual $\delta^{13} \mathrm{C}$ values appear inconclusive in the case of more complex compounds (McCollom et al., 2006; McCollom \& Seewald, 2007, McCollom et al., 2010). The recent study by McCollom and coworkers (2010) clearly demonstrated the importance of the carbon source on hydrocarbon production and isotopic fractionation under hydrothermal conditions. The authors suggested a correlation between the reaction pathways and the carbon source. The probability that several reaction processes control the synthesis of the molecule is higher as the carbon chain length increases. Besides, the reaction pathways involved in the formation of organic compounds in ultramafic-hosted hydrothermal systems are not yet well constrained. The isotopic signature of hydrothermally derived compounds appear consequently to be unpredictable. Therefore other lines of evidence are required. For this purpose, comparison of organic compounds generated by hydrothermal degradation of microorganisms relevant to the sub-seafloor biosphere with the ones detected in fluids from ultramafic-hosted hydrothermal vents may help us understand to what extent the degradation of microorganisms by thermogenic processes may be involved in the production of organic compounds in deep-sea hydrothermal systems. Here, we report a series of experiments of hydrothermal degradation of biomass of the piezophilic archaeon Pyrococcus abyssi under various conditions $\left(200,350\right.$ and $450{ }^{\circ} \mathrm{C} / 40 \mathrm{MPa} / 10$ to $\left.720 \mathrm{~min}\right)$ that are relevant to conditions found in the Rainbow ultramafic-hosted hydrothermal system. 


\section{The Rainbow ultramafic-hosted hydrothermal system}

The Rainbow hydrothermal field is located on the Mid-Atlantic Ridge (MAR), south of the Azores, at $36^{\circ} 14^{\prime} \mathrm{N}, 33^{\circ} 54^{\prime} \mathrm{W}$ at $2300 \mathrm{~m}$ depth (German et al., 1996; Bougault et al., 1998). It is located at the intersection of the non-transform fault system and the ridge faults, on the westfacing flank of the Rainbow ridge at the north-eastern corner of the south Azores Mid-Atlantic Ridge (AMAR) segment. The field size is about $250 \mathrm{~m}$ (east-west) by $60 \mathrm{~m}$ (north-south) and consists of three qualitatively distinct active areas: Thermitière, an organ-pipe-like structure with both hot and diffused fluids that hosts most of the biota, the north-east zone which consists of very active short black smokers and the south-west zone which is less active, exhibiting a lot of old chimneys and a few tall candelabrum-like active chimneys. The Rainbow field is based on peridotite-rich mantle outcrops that are associated with large amounts of $\mathrm{CH}_{4}$ (Charlou et al., 1998). These peridotites undergo serpentinisation, leading to a large production of $\mathrm{H}_{2}$ (Charlou et al., 2002). The temperature of the fluids is around $360^{\circ} \mathrm{C}$ leading to phase separation at depth (Fouquet et al., 1997; Douville et al., 2002). The Rainbow fluids are characterised by high chlorinity $\left(760 \mathrm{mmol} \mathrm{kg}{ }^{-1}\right)$, low $\mathrm{pH}(\mathrm{pH} \sim 3)$, high metal concentrations (e.g. $[\mathrm{Fe}]=24 \mathrm{mmol} \mathrm{kg}^{-}$ ${ }^{1}$ ), significant levels of alkali metals and alkaline earth metals (Douville et al., 2002), low concentration of dissolved $\mathrm{SiO}_{2}$, as well as high levels of dissolved $\mathrm{H}_{2}\left(16 \mathrm{mmol} \mathrm{kg}{ }^{-1}\right)$ and $\mathrm{CH}_{4}$ (2.5 mmol kg${ }^{-1}$ ) (Charlou et al., 1998; Charlou et al., 2002). The presence of $\mathrm{C}_{9} \mathrm{C}_{14} \mathrm{n}$-alkanes, $\mathrm{C}_{9}-\mathrm{C}_{13}$ branched alkanes, $\mathrm{C}_{9}-\mathrm{C}_{11}$ cycloalkanes, $\mathrm{C}_{7}-\mathrm{C}_{12}$ mono-aromatic hydrocarbons, naphthalene and methyl naphthalene, $\mathrm{C}_{13}-\mathrm{C}_{16}$ PAHs (fluorene, phenanthrene, pyrene) and $\mathrm{C}_{9: 0}-\mathrm{C}_{18: 0} \mathrm{n}$ carboxylic acids have also been reported (Holm \& Charlou, 2001; Konn et al., 2009). 


\section{Material and Methods}

\subsection{Choice of experimental conditions}

P. abyssi was chosen for several reasons: it was isolated from a deep-sea vent in the North Fiji basin (Erauso et al., 1993); it is easy to culture; it belongs to archaea and more specifically to the Thermococcales. Thermococcales and Methanococcales were reported to be the main components of the deep-sea biosphere beneath hydrogen-driven hydrothermal field in the Central Indian Ridge (Takai et al., 2004). Thermococcales signatures are commonly found by molecular methods in deep-sea subterranean environments (Roussel et al., 2008). Using culture-dependent methods, they appear to be ubiquitous in deep-sea hydrothermal ecosystems, found both in chimneys and plumes. Different species are able to colonize thermal vents from coastal regions to the deepest hydrothermal field known so far (Zeng et al., 2009). The optimal pressure for growth of a defined species in culture is higher than the pressure of the site from which samples were collected suggesting that strains thriving on hydrothermal chimneys could have a deeper origin (Zeng et al., 2009).

The pressure (P) was set to $40 \mathrm{MPa}$ which corresponds to pressures of deep-sea hydrothermal subterranean fractures or aquifers commonly found on the Mid-Atlantic Ridge and to the sub-optimum pressure for growth of $P$. abyssi. Three temperatures $(\mathrm{T})$ were chosen above the maximum temperature above which $P$. abyssi survives $\left(108{ }^{\circ} \mathrm{C}\right.$ at $40 \mathrm{MPa}$; Erauso et al., 1993). The chosen temperatures are representative of natural conditions observed at the Rainbow site: $200{ }^{\circ} \mathrm{C}$ for diffuse hydrothermal fluids, $350{ }^{\circ} \mathrm{C}$ for hot fluids expelled by black smokers (Charlou et al., 2002; Charlou et al., 2007) and $450{ }^{\circ} \mathrm{C}$ the likely temperature of the chemical reaction zone in the mantle (Charlou et al., 2002; Bach et al., 2004). However, the time to reach chemical equilibrium is not known. Therefore in order to investigate the effect of time on the 
final organic composition recovered, the biomass was exposed for 10, 20, 60, 90, 270 and 720 min at $350{ }^{\circ} \mathrm{C}$. The results at $350{ }^{\circ} \mathrm{C}$ and other experimental considerations led us to choose an exposure time of $60 \mathrm{~min}$ for the two other temperatures $\left(200\right.$ and $\left.450{ }^{\circ} \mathrm{C}\right)$.

We did not add catalysts in these exploratory experiments to limit the number of parameters. Moreover, other published data suggest that direct degradation of organic matter may result in the same organic final mixtures as catalysed degradation, usually by managing temperature and / or reaction time (Nelson et al., 1984; Luijkx et al., 1993; Pan et al., 2009).

\subsection{Pyrococcus abyssi culture}

A primary culture of $P$. abyssi GE5 was grown overnight (12 hours) to stationary growth phase in anaerobic vials according to standard procedures (atmospheric pressure, temperature 94 ${ }^{\circ} \mathrm{C}$; pH 7.0; 2216-S medium; $\mathrm{N}_{2}$ headspace gas; final density $10^{9} / \mathrm{mL}$ ) (Erauso et al., 1993). The composition of 2216-S medium was: yeast extract $0.5 \mathrm{~g} / \mathrm{L}$; peptone $2 \mathrm{~g} / \mathrm{L}$; sea-salts $30 \mathrm{~g} / \mathrm{L}$; PIPES disodium salt $3.46 \mathrm{~g} / \mathrm{l}(10 \mathrm{mM}$, for $\mathrm{pH} 6.1$ to 7.5$)$; resazurin 5 drops/L; elemental sulphur $10 \mathrm{~g} / \mathrm{L}$; distilled water complete to $1 \mathrm{~L}$. The primary culture was used as inoculum for growth in elemental sulphur free conditions using a gas-lift bioreactor as described by Godfroy et al. (2000). Cell density reached $3 \times 10^{8}$ cells $/ \mathrm{mL}$ under stationary growth phase conditions.

Cells were centrifuged at $4000 \mathrm{~g}$ for $40 \mathrm{~min}$ at $4{ }^{\circ} \mathrm{C}$ and pellets washed with Milli-Q saline water containing $\mathrm{Na}_{2} \mathrm{~S} \quad\left(35 \mathrm{~g} / \mathrm{L}\right.$ molecular grade $\left.\mathrm{NaCl}, 2.5 \% \quad \mathrm{Na}_{2} \mathrm{~S}\right)$. Cells were resuspended in the same solution on ice at densities ranging from 1.1 to $1.3 \times 10^{9} / \mathrm{mL}$. This solution was split into $5 \mathrm{~mL}$ Nunc tubes which were stored at $4{ }^{\circ} \mathrm{C}$ for 3 days prior to the hydrothermal degradation experiments. All chemical reagents were from Sigma-Aldrich, St. Louis, USA. Milli-Q saline water spiked with $\mathrm{Na}_{2} \mathrm{~S}$ was used as a negative control in the high pressure and high temperature (HP/HT) experiments (see §3.7). 


\subsection{Apparatus description}

The HP/HT autoclave used to reach hydrothermal conditions has been described in detail elsewhere (Testemale et al., 2005). It consists of a stainless steel autoclave pressurised under pure helium (He), in which a resistive furnace (and the accompanying pieces: thermocouples, insulating ceramics, etc.) and the internal cell that contains the liquid sample are placed. Among other advantages, this design ensures independent control of pressure and temperature, and the consequent possibility to explore the pressure-temperature phase diagram without being restrained along the isochore curves. The pressure and temperature ranges available are 1-200 MPa and $20-1700{ }^{\circ} \mathrm{C}$ respectively.

The internal cell for the liquid sample is depicted on Figure 1. The sample is loaded between the two pistons: at this stage, the volume can be adjusted by varying the space between them ( $2 \mathrm{~cm}$ maximum in our experiments). All the components (external tube and pistons) are made of sapphire. The water tightness is ensured by two silicone rings that seal the space between the tube and the pistons. The furnace does not heat the whole cell, but only the central area (3 cm long) where the sample is located (Testemale et al., 2005). Given the very small space between the pistons and the tube (about 5 microns), the volume of liquid which is out of the heating zone is negligible (less than $1 \%$ of the total volume of sample loaded). As a result we can assume that the entire volume of sample collected at the end of an experiment has been heated.

\subsection{Hydrothermal degradation}

All parts of the sapphire reaction cells (tube, pistons and silicone rings) were washed with Milli-Q water (18.2 Mohm), then with ethanol and acetone for removal of biological and chemical traces and last with Milli-Q water (18.2 Mohm) for cleaning traces of ethanol and 
acetone. The cell was filled with the liquid sample first, then the top and bottom pistons were inserted. This protocol enabled flushing the cell and avoiding air bubbles in contact with the sample (a in Figure 1 left). The final sample load was $\sim 250 \mu \mathrm{L}$ or $\sim 125 \mu \mathrm{L}$, which corresponds to the optimised volume for the $200{ }^{\circ} \mathrm{C}$ and $350{ }^{\circ} \mathrm{C} / 40 \mathrm{MPa}$, or the $450{ }^{\circ} \mathrm{C} / 40 \mathrm{MPa}$ experiments, respectively. This is to take into account the decrease of the solution density with temperature and the resulting volume increase within the cell (pistons moving away from each other). The sapphire reaction cell containing the solution of $P$. abyssi biomass was then introduced into the autoclave. The pressure and temperature were increased up to the set points at $\sim 60 \mathrm{MPa} \min ^{-1}$ and $\sim 660{ }^{\circ} \mathrm{C} \min ^{-1}$. Degradation conditions were maintained for minimum 10 min and up to $720 \mathrm{~min}$. The system was finally brought back to atmospheric conditions at the following rates:

T decrease: $\quad 460{ }^{\circ} \mathrm{C} \min ^{-1}$ down to $120{ }^{\circ} \mathrm{C}$

$36{ }^{\circ} \mathrm{C} \min ^{-1}$ from $120{ }^{\circ} \mathrm{C}$ to $\mathrm{T}_{\text {room }}$

P decrease: $\quad 10 \mathrm{MPa} \min ^{-1}$ down to $10 \mathrm{MPa}$

$$
\text { 1.6 } \mathrm{MPa} \min ^{-1} \text { from } 10 \mathrm{MPa} \text { to } \mathrm{P}_{\mathrm{atm}}
$$

As soon as atmospheric conditions $\left(\mathrm{T}_{\text {room }}, \mathrm{P}_{\mathrm{atm}}\right)$ were reached, the sapphire reaction cell was recovered (b and $\mathrm{c}$ in Figure 1 left). The solution was promptly collected. Dissolved organic compounds were extracted and concentrated by Stir Bar Sorptive Extraction (SBSE). Stir bars were stored until analysis by Thermal Desorption - Gas Chromatography - Mass Spectrometry (TD-GC-MS).

\subsection{Sample preparation: Stir Bar Sorptive Extraction (SBSE)}

The SBSE technique has been described elsewhere (Baltussen et al., 1999). SBSE is an equilibrium technique based on the partitioning of the solutes between a polymer phase 
(PolyDiMethylSiloxane (PDMS)) and the aqueous matrix. PDMS is in a liquid-like state at room temperature, resulting in the retention of the analytes by dissolution rather than by adsorption which is the retention process involved in other extraction techniques. The partitioning of a compound between the PDMS phase and the water phase is directly correlated to its octanol / water partition coefficient $\left(\mathrm{K}_{\mathrm{o} / \mathrm{w}}\right)$, so that the recovery rate of a compound can be easily assessed and calculated. Although SBSE, like all extraction techniques, does not ensure $100 \%$ recovery of all dissolved organic compounds in a given solution, the technique enables extraction of a wide range of compounds and its few contaminants (siloxanes) are readily identifiable. SBSE was particularly suitable for this study which aimed at obtaining a broad qualitative overview of the organic composition of the resulting solutions after thermal degradation of $P$. abyssi. Moreover, the extraction protocol followed in the present work (detailed in the next $\S$ ) is strictly the same as that described by Konn et al. (2009) who also showed its qualitative repeatability for the analyses of hydrothermal fluids (Konn, 2009; Konn et al., 2009). The extraction rates of compounds, especially polar molecules, by SBSE are mainly affected by the $\mathrm{pH}$ and the presence of salts in the solution (Pfannkoch et al., 2001). In our series of experiments the $\mathrm{pH}$ and the chlorinity of the solutions were adjusted, before extraction, to the values of the Rainbow fluids. This was done in order to allow us to confidently make a qualitative comparison between the recovered composition of the hydrothermally-degraded solutions of $P$. abyssi and the recovered composition of hydrothermal fluids from the Rainbow site.

All analytical glassware was combusted for 4 hours at $400{ }^{\circ}$ C. Stir bars (Twisters $\left.{ }^{\circledR}\right)$ used for SBSE were pre-conditioned at $300{ }^{\circ} \mathrm{C}$ for 2 hours under He flow $\left(50 \mathrm{~mL} \mathrm{~min}^{-1}\right)$ to remove any trace of organic matter trapped in the PDMS phase. Directly after recovery of the sapphire cell from the autoclave, the solution was transferred into a glass vial and diluted in $10 \mathrm{~mL}$ of a MilliQ buffer (18.2 Mohm, $\mathrm{pH} \sim 3$ and $\left.\left[\mathrm{Cl}^{-}\right]=760 \mathrm{mM}\right)$. The Twister ${ }^{\circledR}$ was stirred in that solution for 
$60 \mathrm{~min}$ at $300 \mathrm{rpm}$, then removed, dried with a clean tissue and stored at $4{ }^{\circ} \mathrm{C}$ until analysis. Internal standards were not used at this stage, which will not allow quantification. The objectives of this early exploratory work were primarily qualitative in order to lay the groundwork for later and more targeted experiments.

\subsection{TD-GC-MS analyses}

The Twisters ${ }^{\circledR}$ were thermally desorbed in the thermal desorption system (TDS-2, GERSTEL GmbH \& Co. KG, Mülheim an der Ruhr, Germany) mounted on a 6890 Agilent GC (Agilent Technologies, Little Falls, DE, USA) equipped with a 5973 quadrupole mass spectrometer detector (MSD). The TDS was coupled to a cooled injection system (CIS3, GERSTEL GmbH \& Co. KG, Mülheim an der Ruhr, Germany) for cryofocusing of the analytes prior to transfer onto the column. Liquid nitrogen was used to cool and maintain the CIS at -100 ${ }^{\circ} \mathrm{C}$ while the Twister ${ }^{\circledR}$ was desorbed at $300{ }^{\circ} \mathrm{C}$ under He flow in the TDS. The CIS was then heated to $250{ }^{\circ} \mathrm{C}$. Separation was achieved on an HP5-MS capillary column $(30 \mathrm{~m}$ x $0.25 \mathrm{~mm}$ i.d. $\mathrm{x} 0.25 \mu \mathrm{m}$ film thickness). The GC column temperature was held first at $40{ }^{\circ} \mathrm{C}$ for $1 \mathrm{~min}$, then ramped from 40 to $320{ }^{\circ} \mathrm{C}$ at $12{ }^{\circ} \mathrm{C} \mathrm{min}-1$ and held at $320{ }^{\circ} \mathrm{C}$ for $2 \mathrm{~min}$. He was used as carrier gas with a flow of $1.2 \mathrm{~mL} \mathrm{~min}^{-1}$. The mass spectrometer was operated in electron impact (EI) mode at $70 \mathrm{eV}$ ionisation energy and scanned from 10 to $500 \mathrm{Da}$. Data were acquired and processed by Chemstation software. A tentative identification of individual organic compounds is proposed based on the comparison of recorded mass spectra in the NIST05a library and the retention time of the compound. 


\subsection{Control experiments and reproducibility}

The Total Ion Current (TIC) of a properly cleaned Twister® after conditioning (§3.5) exhibits six characteristic and clearly distinct peaks of siloxanes. They are inherent to the PDMS phase and cannot be removed by further conditioning (Figure 2) (Baltussen et al., 1999). These six peaks constitute reference points and have been highlighted in grey on the illustrated chromatograms. Among each batch of conditioned Twisters ${ }^{\circledR}$, one was selected randomly and stored as such. These dry blanks were not used to trap degradation products. They were analysed during the same run as the other stir bars used for extraction of the hydrothermallydegraded solutions of $P$. abyssi. TICs for the dry blanks only revealed the typical Twister® signature peaks (Figure 2) which indicates that the stir bars used for the experiments were clean and that no contamination occurred from conditioning to analyses.

A negative control experiment was also carried out. For that purpose, the same Milli-Q saline water at $2.5 \% \mathrm{Na}_{2} \mathrm{~S}$ used for preparing $P$. abyssi solutions was exposed for 10 min at 350 ${ }^{\circ} \mathrm{C} / 40 \mathrm{MPa}$. A detailed analysis of the TIC demonstrated that very few organic compounds could be recovered and detected using our methodology after hydrothermal treatment of the brine buffer (Figure 2). Moreover, those compounds that were detected consisted of polymers additives and derivatives as well as phthalates that are very commonly found in organic geochemistry analyses because they originate from plastics.

The $350{ }^{\circ} \mathrm{C} / 40 \mathrm{MPa} / 10 \mathrm{~min}$ experiment was repeated using aliquots of the same $P$. abyssi solution (same Nunc tube) loaded into two different sapphire cells and extracted with two different stir bars. The chromatograms correlated well (Figure 2). A detailed interpretation of the TIC revealed that differences consisted of only abundances variation. Both experiments 
resulted in the same recovered organic compound composition. As a conclusion, the qualitative repeatability of the experiment is good.

\section{Results}

Over 300 peaks could be detected in each TIC and half of them were tentatively identified. We will focus here on compounds that could be confidently identified and that are relevant to hydrothermal processes based on formerly published data by Konn et al. (2009). Table 1 lists these compounds of potential interest and summarises their presence / absence under the different sets of $\mathrm{T} / \mathrm{P} /$ time conditions investigated in the present study. Figure 3 shows that the general pattern of the TICs obtained in the present experiments clearly differs from the TICs recorded after extraction of hydrothermal fluids from the Rainbow site (Konn et al., 2009). Noteworthy no aliphatic alkanes could be detected from the $P$. abyssi hydrothermal degradation experiments. These compounds have been detected in hydrothermal fluids.

\section{$4.1200{ }^{\circ} \mathrm{C} / 40 \mathrm{MPa} / 60 \mathrm{~min}$}

Only a few organic compounds could be detected in the $200{ }^{\circ} \mathrm{C}$ experiment using our approach (Table 1, Figure 3). Also, they differed from hydrothermally derived compounds reported by Konn et al. (2009), with the exception of toluene, xylene, naphthalene and $\mathrm{C}_{8: 0}$ to $\mathrm{C}_{12: 0}$ linear fatty acids. The resulting solution exhibited a frothy aspect (c on Figure 1 left), which was not observed in any of the higher temperature experiments (b on Figure 1 left).

\section{$4.2350{ }^{\circ} \mathrm{C} / 40 \mathrm{MPa} / 10-720 \mathrm{~min}$}

Regardless of the exposure time, the experiments resulted in a crystal clear solution (b on Figure 1 left). In the 10 min experiment only toluene, styrene and $C_{8: 0}$ to $C_{16: 0}$ carboxylic acids 
could be recovered and identified. Naphthalene and alkylated bicyclic aromatic hydrocarbons (BAHs) could be detected from 20 min exposure. Alkyl-benzenes, other than toluene and styrene, appeared after 90 min. Polycyclic aromatic hydrocarbons (PAHs) occurred only in the 270 and 720 min experiments (Table 1). Linear fatty acids seemed to consistently vanish with increasing exposure time until they were absent in the 720 min experiment (Table 1, Figure 4). Clearly the time of degradation affected the organic composition of the resulting solutions. A striking difference could be observed between the 10 and 720 min, e.g. in Figure 5 (b and c) one can see the evolution of peaks corresponding to the alkyl-benzenes. The longest time of exposure generated the largest amount of organic compounds that could be recovered and identified using our method. Toluene, styrene, $\mathrm{C}_{9}-\mathrm{C}_{12}$ alkyl-benzenes, naphthalene, $\mathrm{C}_{12}-\mathrm{C}_{15}$ alkyl-BAHs, $\mathrm{C}_{14}-\mathrm{C}_{16}$ alkyl-phenanthrenes or anthracenes could be identified after 720 min of hydrothermal treatment (Table 1).

\section{$4.3450{ }^{\circ} \mathrm{C} / 40 \mathrm{MPa} / 60 \mathrm{~min}$}

Within our set of experimental conditions, $450{ }^{\circ} \mathrm{C} / 40 \mathrm{MPa} / 60 \mathrm{~min}$ conditions clearly lead to the production of the greatest variety of organic compounds (Table 1). Toluene, styrene, $\mathrm{C}_{8}-\mathrm{C}_{16}$ alkyl-benzenes, naphthalene, $\mathrm{C}_{11}-\mathrm{C}_{16}$ alkyl-BAHs, even carbon number $\mathrm{C}_{12}-\mathrm{C}_{18}$ PAHs and $\mathrm{C}_{15}-\mathrm{C}_{18}$ alkyl-phenanthrenes where detected after degradation of $P$. abyssi at $450{ }^{\circ} \mathrm{C}$ and $40 \mathrm{MPa}$ for 60 min. Linear fatty acids were still present although not the entire series; only $\mathrm{C}_{9: 0}, \mathrm{C}_{10: 0}$ and $\mathrm{C}_{16: 0}$ could be identified. That observation is consistent with a recent study by Pan and coworkers (2009) who observed a real increase in the production of organic compounds from 400 ${ }^{\circ} \mathrm{C}$ in the absence of a catalyst. At $450{ }^{\circ} \mathrm{C}$ and $40 \mathrm{MPa}$ conditions are near the critical isochore line of (salty) water, which may partly explain the variety and number of compounds observed at $450{ }^{\circ} \mathrm{C}$ compared to the yields from other experimental conditions (Figure 6). 


\subsection{General observations}

High temperature or long exposure times at lower temperature seem to favour the thermogenic generation of organic compounds from $P$. abyssi biomass. Indeed, the greatest variety of organic compounds was observed in the $450{ }^{\circ} \mathrm{C} / 10 \mathrm{~min}$ and $350{ }^{\circ} \mathrm{C} / 720 \mathrm{~min}$ experiments which is indicative of the similar role of temperature and time on the chemical variety. The example of alkyl-benzenes is representative and illustrates that trend (Figure 5).

Some fatty acids $\left(\mathrm{C}_{8: 0}-\mathrm{C}_{16: 0}\right)$ were detected in the resulting solutions from all temperatures (Table 1, Figure 3). The presence / absence of individual n-carboxylic acids appeared random with respect to temperature in our series of experiments so that no clear effect of temperature on the generation of linear fatty acids could be determined.

\section{Discussion}

\section{$5.1200{ }^{\circ} \mathrm{C} / 40 \mathrm{MPa} / 60 \mathrm{~min}$}

The near absence of organic compounds that could be detected using our method at 200 ${ }^{\circ} \mathrm{C}$ is in good agreement with a recent paper that reports on the degradation of kerogen at $50 \mathrm{MPa}$ and $200,320,360$ and $400{ }^{\circ} \mathrm{C}$ with or without the presence of a catalyst (Pan et al., 2009). In all their experiments at $200{ }^{\circ} \mathrm{C}$ only a few organic compounds could be detected. We suggest an incomplete degradation of $P$. abyssi cells at $200{ }^{\circ} \mathrm{C}$. Partial degradation would generate molecules too large to be soluble in water or to be detected by GC-MS using the current settings of this experiment. Cell membranes consist of phospholipids (nonpolar chains linked to a polyol backbone bound to a phosphate + alcohol unit) which are packed together in a bilayer through low energy Van der Waals interactions (for further details refer to Berg et al. (2007). In archaeal lipids, the nonpolar chains are joined to the polyol by ether bonds. $200{ }^{\circ} \mathrm{C} / 40 \mathrm{MPa}$ conditions 
may hold sufficient energy to break the low energy intermolecular bonds but too little to cleave intramolecular covalent bonds, especially the strong ether bonds. The consistently observed soapy aspect of the recovered solution may be explained by the release of free membrane lipids that then readily formed micelles due to their amphiphilic properties (Berg et al., 2007). At higher temperatures, $\mathrm{T} \geq 350{ }^{\circ} \mathrm{C}$, the experiments resulted in a crystal clear solution which suggests a full degradation of the cells. However, because of slower kinetics at $200{ }^{\circ} \mathrm{C}$, we cannot exclude the possible formation of detectable organic compounds provided a longer exposure time is allowed. For instance, Kawamura and coworkers (1986) reported the formation of organic acids from kerogen heated at only $100{ }^{\circ} \mathrm{C}$ for a period of two weeks. In our case, a dedicated and longer kinetics study would be necessary to derive quantitative information.

\subsection{Experiments at $\mathrm{T} \geq 350^{\circ} \mathrm{C}$}

\subsubsection{Aliphatic hydrocarbons}

Neither saturated nor cyclic hydrocarbons could be found in any of the experiments. This was unexpected because they are common subunits of cell membranes. Glycerol dialkyl glycerol tetraethers (GDGTs) are major constituents of archaea cell membranes. GDGTs are comprised of two ether-bound nonpolar chains; most often saturated hydrocarbons which consist in $\mathrm{C}_{20}-\mathrm{C}_{40}$ isoprenoids that may contain cyclopentane and cyclohexane moieties, phytane $\mathrm{C}_{40}$ being the most common (Hanford \& Peeples, 2002; Bouloubassi et al., 2006; Gontharet et al., 2009). It is worth noting that Pyrococcus spp. usually does not have those moieties (Figure 7). Cleavage of the ether bonds would release isoprenoids. However, those saturated hydrocarbons are unlikely to be detected as such because they probably undergo further chemical reactions under our experimental conditions, i.e. in supercritical water. 
Dramatic changes in the physical and chemical properties of water occur as temperature increases. In particular, in the critical domain and near the critical isochore (Figure 6), collective interactions between molecules develop and are responsible for density fluctuation. These fluctuations reach their maximum at the critical point (for seawater: $\mathrm{T}_{\mathrm{c}}=403-406{ }^{\circ} \mathrm{C}, \mathrm{P}_{\mathrm{c}}=28.5$ 30.2 MPa; Bischoff \& Pitzer, 1985) (Figure 6). Large variations in density, dielectric constant, solubility parameters and ionic product are observed in the supercritical domain (e.g. Shock, 1992). These variations are at the origin of the specific solvent properties of superheated water which are similar to those of nonpolar organic solvents at room temperature, thus facilitating reactions with and between organic compounds. Organic molecules that are nonreactive in liquid water at atmospheric pressure undergo many chemical reactions when the temperature is increased to $250-350{ }^{\circ} \mathrm{C}$. Supercritical water becomes an excellent solvent for ionic condensations, cleavages, cyclisation, hydrolysis, oxidations, hydrogenations and hydroformylations. The water can have multiple roles. It can act as solvent, reactant, catalyst, proton donor, complexing agent or hydration agent. The main reaction pathways that have been identified so far in supercritical water are those with an ionic or radical character. These reactions seem to occur in distinct zones of the $\mathrm{P}-\rho-\mathrm{T}$ ( $\rho$ is density) surface diagram of water and to compete against each other in the vicinity of the critical point (Watanabe et al., 2004). Additionally, molecular rearrangements, i.e. reactions in which neither radical nor ionic intermediates are involved, possibly proceed near the critical region of water (Akiya \& Savage, 2002). Unfortunately reaction pathways and their kinetics occurring in supercritical water are still largely uncharacterised (Simoneit, 1992; Peterson et al., 2008). As a result, we do not know which chemical reactions may affect the saturated hydrocarbons of GDGTs during hydrothermal treatment. Therefore we are unable to describe the specific hydrothermal reaction(s) products i.e. 
what could be detected in our experiments as the organic signature of the saturated hydrocarbons of the GDGTs after hydrothermal treatment of the archaeal biomass.

\subsubsection{Aromatic hydrocarbons}

The organic fraction that could be recovered from our long exposure $350{ }^{\circ} \mathrm{C}$ experiment and from our $450{ }^{\circ} \mathrm{C}$ treatments, exhibited numerous alkylated mono-, bi- and poly- cyclic aromatic hydrocarbons showing an increasing degree of alkylation with temperature and time. This is consistent with the findings by Pan and coworkers (2009). Also, aromatic rings have been shown to be stable under hydrothermal conditions though the substituent groups of aromatic compounds will react without affecting the ring (McCollom et al., 2001). Aromatic compounds consistently occur in various geological environments including oil-field brines and hydrothermal fluids (Simoneit et al., 1988; Fisher \& Boles, 1990; Konn et al., 2009). As a consequence, the detection of aromatic compounds in our experiments is in good agreement with thermodynamic calculations, field observations and other experiments.

Aromatic compounds can be formed from sugars under hydrothermal conditions with or without catalysis. For example, degradation of D-fructose at 290 to $400{ }^{\circ} \mathrm{C}$ and pressures of 27 MPa (Luijkx et al., 1993) and of pure cellulose under similar conditions in the presence of sodium carbonate $\left(\mathrm{Na}_{2} \mathrm{CO}_{3}\right)$ (Nelson et al., 1984) generated monocyclic aromatic compounds. Sugars that are ubiquitous to all organisms may have served as precursors for the production of the aromatic hydrocarbons detected in our experiments. These aromatic compounds could also be derived from the saturated hydrocarbons of the GDGTs via cleavage, cyclisation and dehydration reactions in the superheated water (see $\$ 5.2 .1)$. 


\subsubsection{Carboxylic acids}

Carboxylic acids are ubiquitous in all living organism, $\mathrm{C}_{16: 0}$ and $\mathrm{C}_{18: 0}$ being the most common (Madigan \& Martinko, 2005). Fatty acids are also pervasive in many geological contexts indicating that they persist at a wide range of temperatures and pressures. Therefore they have been used as bacterial lipid biomarkers in various environments such as cold seeps (Gontharet et al., 2009), mud-volcanoes (Bouloubassi et al., 2006) and ice shelfs (Jungblut et al., 2009). Moreover, carboxylic acids have been the focus of extensive research in geosciences because of their potential involvement in numerous biogeochemical processes. In sedimentary basins, they have been suggested as a precursor to natural gas and oil. From a biologic perspective, free organic acids represent a source of carbon for microorganisms.

Numerous laboratory experiments have shown that carboxylic acids can be produced by heating organic matter in petroleum source rocks, oil and recent sediments (e.g. Kawamura et al., 1986; Seewald et al., 1990; Andresen et al., 1994; Borgund \& Barth, 1994; Knauss et al., 1997). The production has been generally attributed to cleavage of kerogen fragments (e.g. Giles \& Marshall, 1986), although additional oxidation reactions have been suggested to be involved (e.g. Borgund \& Barth, 1994). The latter hypothesis is supported by laboratory experiments that have shown oxidative degradation of aqueous n-alkanes proceeds in a sequence of reactions leading to the generation of carboxylic acids in the presence of a suitable oxidising agent (Seewald, 2001b). A model by Seewald (2001b) suggested that this pathway could explain the observed concentration and distribution of organic acids in basin brines. Considering that water becomes a very efficient oxidising agent at our experimental conditions, it is very likely that this reaction pathway occurred in our case. Fatty acids may form easily via oxidation of aliphatic hydrocarbons released from the GDGTs. 
It is notable that $\mathrm{C}_{8}-\mathrm{C}_{16} \mathrm{n}$-carboxylic acids seem to disappear with time at $350{ }^{\circ} \mathrm{C}$. Longer chain fatty acids have been observed by others to decompose at $350-325^{\circ} \mathrm{C} / 35 \mathrm{MPa}$ to shorter chain compounds - mainly n-carboxylic acids and n-alkanes - with $\mathrm{CO}_{2}$ and $\mathrm{CH}_{4}$ being the ultimate products under suitable redox buffered conditions (Seewald, 2001a; McCollom \& Seewald, 2003). Formic and acetic acids persisted over hundreds of days in these experiments. Low molecular weight organic compounds cannot be detected using our method. Shortening of carbon chains is very likely happening in our treatments but will need further investigation and support. Another explanation for the loss of $\mathrm{C}_{8: 0}-\mathrm{C}_{16: 0}$ carboxylic acids in our system is that they may form N-bearing condensation products (Rushdi \& Simoneit, 2004). A wide range of Nbearing compounds were detected in our experiments. These compounds are not presented and detailed here for the sake of clarity and because there are no published data reporting on the presence of N-bearing compounds in hydrothermal fluids from the Rainbow site.

\subsection{Implications for the Rainbow hydrothermal system}

The present design of experiments involved a single species of microorganism as a feasibility study for such investigations. A more satisfactory approach, based on characterisations of microbial species found in the subsurface biosphere, would be to consider a mix of Thermococcales, Methanococcales, Thermotogales and Epsilonproteobacteria (Fry et al., 2008; Nakagawa et al., 2008; Roussel et al., 2008; Takai et al., 2001). However, relevant data are lacking for the determination of the most representative proportion of each group of microorganisms in the final mixture to be tested in our experiments and any arbitrary proportion would be as speculative as examining only one species, $P$. abyssi. Furthermore, our results using the biomass of a single species are consistent with those obtained in similar experiments from bulk kerogen $(\mathrm{H} / \mathrm{C}=0.12$ and $\mathrm{O} / \mathrm{C}=0.22)$ whith an elemental composition of $67 \% \mathrm{C}, 8.3 \% \mathrm{H}$, 
$14.9 \% \mathrm{O}$ and $3 \% \mathrm{~N}$. The elemental composition of $P$. abyssi is similar. Indeed, $90 \%$ of the cell weight of a microorganism, regardless of the species, is comprised roughly of $\mathrm{C}_{5} \mathrm{H}_{7} \mathrm{O}_{2} \mathrm{~N}$, i.e. $51,3 \% \mathrm{C}, 6.2 \% \mathrm{H}, 28.3 \% \mathrm{O}$ and $12.4 \% \mathrm{~N}$ (wt \%) which gives $\mathrm{H} / \mathrm{C}=0.12$ and $\mathrm{O} / \mathrm{C}=0.53$ (Kengen \& Stams, 1994). This suggests that the atomic composition of the initial organic matter and the degradation processes may be prevailing factors in controlling the resulting composition in organic compounds after hydrothermal degradation of the biomass.

The potential sub-seafloor biosphere beneath active hydrothermal systems is likely to be present in zones where temperatures do not exceed $150{ }^{\circ} \mathrm{C}$. As such the hydrothermal degradation of microorganisms is probably episodic and induced by sudden invasion of hot fluids $\left(\mathrm{T}>350^{\circ} \mathrm{C}\right.$ ) into the lower temperature habitats. Thus the short-time (probably several minutes to several tens of minutes) kinetics of hydrothermal degradation reaction and non-equilibrium conditions would be far more relevant to investigate the organic compounds generated by hydrothermal degradation in natural environments. However, chemical equilibrium may be established after the fluid is no longer in contact with the subsurface biosphere. This may change the final organic composition in the fluid. We cannot assure that our system reached chemical equilibrium. Whether or not this criterion is also met in hydrothermal fluids is unknown because hydrothermal vents are open systems. This means that, admittedly compounds that were not detected in our experiments may well form after a longer time, but non-equilibrium chemical states may be relevant to field conditions (Askhabov, 2008).

The redox conditions were not characterized in our experiments and they may not have been as reducing as the Rainbow hydrothermal field fluids. Yet the redox state is the crucial parameter that govern chemical equilibria. Thermodynamics are correlated to the redox state via the molecular $\mathrm{H}_{2}$ and $\mathrm{O}_{2}$ fugacities (Shock, 1990; Shock, 1992). Different redox conditions will lead to different thermodynamic equilibria and thus to different prediction of the final organic 
products of hydrothermal degradation. Geological environments are buffered by mineral assemblages which are well constrained for several types of systems (e.g. Shock, 1992). However, there is no consensus about which mineral assemblages buffer the fluids in ultramafichosted hydrothermal systems. This is the major reason why we did not buffer our experiments. Knowing the concentration of $\mathrm{H}_{2}$ or $\mathrm{O}_{2}$ would have provided useful information on the redox state of the solutions; unfortunately the current experimental set-up does not allow gas measurements within the internal cell during or after the degradation phase.

Considering the aforementioned points the fact that no n-alkanes, branched or cyclic alkanes could be detected in our experiments is likely due to the redox conditions which were not reducing enough for them to persist (e.g. Shock, 1990; Shock, 1992). As a difference alkylbenzenes were numerous. These two facts would be consistent with the observation of an opposite trend (clear presence of aliphatic hydrocarbons $\left(\mathrm{C}_{9}-\mathrm{C}_{14}\right)$ and absence of alkyl-benzenes larger than $\mathrm{C}_{8}$ ) in the highly reducing fluids of the Rainbow site. However, our findings that hydrothermal degradation of the subsurface biosphere does not generate aliphatic hydrocarbons may well be independent of the redox conditions. Consequently it would indicate that a portion of the aliphatic hydrocarbons may have an abiogenic origin in hydrothermal fluids of the Rainbow site. Pikovskii and coworkers (2004) reported isoprenoids and low molecular alkanes in serpentinites that they thought to be of abiogenic origin; mainly because the isoprenoids had an atypical structure compared to their biogenic counterparts and also because the observed amounts of low molecular alkanes could not be generated only by thermal degradation of microorganisms. n-Alkanes are prime candidates in terms of abiogenic origin because they can readily be synthesised via FTT reactions (e.g. Shock, 1992; McCollom \& Seewald, 2007).

Altogether our results suggest that the production of aromatic compounds by degradation of the sub-seafloor biosphere via thermogenic processes is possible and could partly account for the 
presence of alkyl-benzenes, alkyl-naphtalenes and PAHs in fluids from the Rainbow field (Konn et al., 2009). These compounds are of lower molecular weight and exhibited fewer side groups in the hydrothermal fluids compared to our experiments which we suggest is due to the high activity of $\mathrm{H}_{2} \mathrm{~S}$ and presence of elemental sulphur in the fluids. The reactivity of the substituent groups of the aromatic ring, including cleavage of $\mathrm{C}-\mathrm{C}$ bonds and loss of a substituent, is enhanced by dissolved sulphur compounds whereas redox conditions have only minimal effect (McCollom et al., 2001).

Synthetic standards were not used and this precludes determination of carboxylic acids concentrations in our experiments. Nonetheless, relative abundances can be estimated within a sample and samples compared to each other. Even though different factors can affect the recovery of alkanoic acids by SBSE, these factors either affect the whole acid series the same way or they are purely related to the PDMS phase. The presence of salt generally enhances the recovery of polar compounds such as n-carboxylic acids. The carboxylate ion is more polar than the acid form, however the pKa value for the $\mathrm{C}_{8: 0}-\mathrm{C}_{18: 0}$ alkanoic acid series is 4.78 , so that at a $\mathrm{pH}$ of 3 (our conditions) most are in their protonated form. It has been observed that short chain fatty acids partition more poorly into PDMS than predicted based on their polarity and that long chain fatty acids $\left(>\mathrm{C}_{16}\right)$ seem to partition much more slowly into the PDMS phase because of a diffusion effect (E. A. Pfannkoch, personal communication). These phase partitioning phenomena are independent of the aqueous matrix composition. Diffusion is time dependent and all samples of both the present study and hydrothermal fluids were extracted for the same duration (60 min).

Estimation of the relative abundance of individual n-carboxylic acids indicates a different distribution pattern of the recovered fatty acids between the Rainbow fluids and our experiments (Figure 8). The hydrothermal degradation of $P$. abyssi biomass seems to generate mostly shorter 
chain n-alkanoic acids whereas heavier n-alkanoic acids seem to dominate in the Rainbow fluids. This could be related to the diversity of the natural subsurface biosphere which is likely to include abundant bacterial populations having long fatty acids in their major lipid components. Whether or not this observation is significant is unclear. Differences in redox conditions should not affect the distribution of the n-carboxylic acids due to their chain length because their activities are very similar except for formic and acetic acid (Shock, 1990). Nonetheless, drawing conclusions at this point would be too speculative considering that factors that control the relative abundances of organic compounds in geologic environments are still uncertain. Moreover, physical and chemical processes occurring in hydrothermal systems are very poorly constrained and understood. Many different processes could possibly affect carboxylic acids in hydrothermal systems. (i) They can adsorb on rock or mineral surfaces at or below the seafloor and thus be retained, and possibly segregated depending on the chain length. (ii) They could form via oxidation of either n-alkanes derived from microorganism (long chain) or abiogenic (FTT) nalkanes (short chain). (iii) FTT type reactions may directly synthesise carboxylic acids potentially leading to short chain predominance (McCollom et al., 1999; Rushdi \& Simoneit, 2001). (iv) Fatty acids can be condensed with nitrogen to generate N-bearing compounds (Rushdi \& Simoneit, 2004). The differences observed in the distribution of organic acids may only indicate that their formation and dissolution in our experiments and in hydrothermal fluids are controlled by distinct processes. In addition, the mere presence of linear fatty acids in our experiments suggests that a portion of the n-carboxylic acids detected in the Rainbow hydrothermal fluids $\left(\mathrm{C}_{9: 0}-\mathrm{C}_{18: 0}\right)$ by Konn et al. (2009) may originate from hydrothermal degradation of microorganisms. 


\section{Conclusions}

P. abyssi biomass was hydrothermally degraded in order to investigate the extent of thermogenic processes on the production of organic compounds at Mid-Ocean Ridge ultramafichosted hydrothermal systems and to investigate the origin of these compounds. On the one hand, our results show that part of the aliphatic hydrocarbons may have an abiogenic origin in hydrothermal fluids from the Rainbow field. On the other hand, the presence of aromatic hydrocarbons in our experiments indicates that thermogenic processes, with a possible biogenic contribution, may be involved to some extent in the origin of the alkyl-benzenes, alkylnaphthalenes and PAHs in the fluids from the Rainbow ultramafic-hosted hydrothermal system. Also, the presence of $n$-carboxylic acids in our experiments suggests that a portion of the $n$ carboxylic acids present in the fluids from the Rainbow field may have a biogenic origin. Furthermore, the distribution of fatty acids in our experiments strongly differed from field observations at the Rainbow site, which could indicate that their formation and partitioning (fluid / rock \& minerals) are controlled by distinct processes in our experimental settings when compared to the conditions found in natural hydrothermal systems. Our preliminary study presented here indicates that further experiments have to be carried out in order to define the effects of various parameters on the final products of the hydrothermal degradation of biomass. The role of redox conditions, composition of the initial biomass (atomic, molecular and species), catalysis and kinetics will have to be investigated. However, despite the impossibility of setting experimental conditions that perfectly mimic field conditions this study definitely provides relevant data for the understanding of geochemical processes in hydrothermal systems. It highlights how complex the formation of organic molecules is in high temperature and high pressure environments and illustrates the issues of molecular cleavage, recombination and of 
carbon sources mixing. This work shows the importance of the subsurface biosphere impact on the geochemistry of hydrothermal fluids.

1

2

3

4

5

6

7

8

9

10

11

12

13

14

15

16

17

18

19

20

21

22

23

24

25

26

27

28

29

30

31

32

33

34

35

36

37

38

39

40

41

42

43

44

45

46

47

48

49

50

51

52

53

54

55

56

57

58

59

60 


\section{Acknowledgements}

We are very thankful to Dr. Marie-Anne Cambon-Bonavita, Dr. Volker Brüchert and Dr. Anne Godfroy for their constructive discussions about microbiology. We are also grateful to Edward A. Pfannkoch from Gerstel Inc. for giving precious advice and sharing his expertise. We very much appreciated all anonymous reviewers' comments which guided us in improving this paper a lot. This work was partly funded by the MoMARnet (Monitoring deep sea floor hydrothermal environments on the Mid-Atlantic Ridge: a Marie Curie Research Training Network) project. 


\section{References}

Akiya N, Savage PE (2002) Roles of Water for Chemical Reactions in High-Temperature Water. Chemical Reviews, 102, 2725-2750.

Andresen B, Throndsen T, Barth T, Bolstad J (1994) Thermal generation of carbon dioxide and organic acids from different source rocks. Organic Geochemistry, 21, 1229-1242.

Askhabov A (2008) The quataron hypothesis of the origin of life. Doklady Biological Sciences, 418, 50-52.

Bach W, Garrido CJ, Paulick H, Harvey J, Rosner M (2004) Seawater-peridotite interactions: First insights from ODP Leg 209, MAR $15^{\circ}$ N. Geochemistry Geophysics Geosystems, 5, Q09F26, doi:10.1029/2004GC000744.

Baltussen E, Sandra P, David F, Cramers C (1999) Stir bar sorptive extraction (SBSE), a novel extraction technique for aqueous samples: Theory and principles. Journal of Microcolumn Separations, 11, 737-747.

Berg JM, Tymoczko JL, Stryer L (2007) Lipids and Cell Membranes. In: Biochemistry 6th edition. W H Freeman \& Co, pp. 326-332.

Bischoff JL, Pitzer KS (1985) Phase relations and adiabats in boiling seafloor geothermal systems. Earth and Planetary Science Letters, 75, 327-338.

Borgund AE, Barth T (1994) Generation of short-chain organic acids from crude oil by hydrous pyrolysis. Organic Geochemistry, 21, 943-952.

Bougault H, Aballea M, Radford-Knoery J, Charlou JL, Baptiste PJ, Appriou P, Needham HD, German C, Miranda M (1998) FAMOUS and AMAR segments on the Mid-Atlantic Ridge: ubiquitous hydrothermal $\mathrm{Mn}, \mathrm{CH} 4, \delta^{3} \mathrm{He}$ signals along the rift valley walls and rift offsets. Earth and Planetary Science Letters, 161, 1-17.

Bouloubassi I, Aloisi G, Pancost RD, Hopmans E, Pierre C, Sinninghe Damsté JS (2006) Archaeal and bacterial lipids in authigenic carbonate crusts from eastern Mediterranean mud volcanoes. Organic Geochemistry, 37, 484-500.

Charlou J, Donval J, Konn C, Birot D, Sudarikov S, Jean-Baptiste P, Fouquet Y, cruise SPotS (2007) High Hydrogen and abiotic hydrocarbons from new ultramafic hydrothermal sites between $12^{\circ} \mathrm{N}$ and $15^{\circ} \mathrm{N}$ on the Mid Atlantic Ridge- Results of the Serpentine cruise (March 2007). In: Eos Transactions AGU, Fall Meeing Supplement, Abstract T51F-04.

Charlou JL, Donval JP, Fouquet Y, Jean-Baptiste P, Holm N (2002) Geochemistry of high $\mathrm{H}_{2}$ and $\mathrm{CH}_{4}$ vent fluids issuing from ultramafic rocks at the Rainbow hydrothermal field (36 14 'N, MAR). Chemical Geology, 191, 345-359.

Charlou JL, Donval JP, Konn C, Ondreas H, Fouquet Y, Jean Baptiste P, Fourré E (InPress) High production and fluxes of $\mathrm{H}_{2}$ and $\mathrm{CH}_{4}$ and evidence of abiotic hydrocarbon synthesis by serpentinization in ultramafic-hosted hydrothermal systems on the Mid-Atlantic Ridge. In: Diversity of Hydrothermal Systems on Slow-spreading Ocean Ridges (eds Rona P, Devey C, Dyment J, Murton B).

Charlou JL, Fouquet Y, Bougault H, Donval JP, Etoubleau J, Jean-Baptiste P, Dapoigny A, Appriou P, Rona PA (1998) Intense $\mathrm{CH}_{4}$ plumes generated by serpentinization of ultramafic rocks at the intersection of the $15^{\circ} 20^{\prime} \mathrm{N}$ fracture zone and the Mid-Atlantic Ridge. Geochimica et Cosmochimica Acta, 62, 2323-2333. 
Cowen JP, Giovannoni SJ, Kenig F, Johnson HP, Butterfield D, Rappe MS, Hutnak M, Lam P (2003) Fluids from Aging Ocean Crust That Support Microbial Life. Science, 299, 120123.

Douville E, Charlou JL, Oelkers EH, Bienvenu P, Jove Colon CF, Donval JP, Fouquet Y, Prieur D, Appriou P (2002) The rainbow vent fluids $\left(36^{\circ} 14^{\prime} \mathrm{N}, \mathrm{MAR}\right)$ : the influence of ultramafic rocks and phase separation on trace metal content in Mid-Atlantic Ridge hydrothermal fluids. Chemical Geology, 184, 37-48.

Erauso G, Reysenbach A-L, Godfroy A, Meunier J-R, Crump B, Partensky F, Baross J, Marteinsson V, Barbier G, Pace N, Prieur D (1993) Pyrococcus abyssi sp. nov., a new hyperthermophilic archaeon isolated from a deep-sea hydrothermal vent. Archives of Microbiology, 160, 338-349.

Ferris JP (1992) Chapter 6 Chemical markers of prebiotic chemistry in hydrothermal systems. Origins of Life and Evolution of Biospheres, V22, 109-134.

Fiebig J, Woodland AB, Spangenberg J, Oschmann W (2007) Natural evidence for rapid abiogenic hydrothermal generation of $\mathrm{CH}_{4}$. Geochimica et Cosmochimica Acta, 71, 30283039.

Fisher JB, Boles JR (1990) Water--rock interaction in Tertiary sandstones, San Joaquin basin, California, U.S.A.: Diagenetic controls on water composition. Chemical Geology, 82, 83101.

Fouquet Y, Charlou JL, Ondreas H, Knoery J, Donval JP, Douville E (1997) Discovery and first submersible investigations on the Rainbow hydrothermal field on the MAR $\left(36^{\circ} 14^{\prime} \mathrm{N}\right)$, Eos Transactions AGU, 78, 832.

Frost BR, Beard JS (2007) On Silica Activity and Serpentinization. J. Petrology, 48, 1351-1368.

Fry JC, Parkes RJ, Cragg BA, Weightman AJ, Webster G (2008) Prokaryotic biodiversity and activity in the deep subseafloor biosphere. FEMS Microbiology Ecology, 66, 181-196.

German CR, Klinkhammer GP, Rudnicki MD (1996) The Rainbow Hydrothermal Plume, $36^{\circ} 15^{\prime} \mathrm{N}$, MAR. Geophysical Research Letters, 23, 2979-2982.

Giles MR, Marshall JD (1986) Constraints on the development of secondary porosity in the subsurface: Re-evaluation of processes. Marine and Petroleum Geology, 3, 243-255.

Godfroy A, Raven NDH, Sharp RJ (2000) Physiology and continuous culture of the hyperthermophilic deep-sea vent archaeon Pyrococcus abyssi ST549. FEMS Microbiology Letters, 186, 127-132.

Gontharet S, Stadnitskaia A, Bouloubassi I, Pierre C, Damsté JSS (2009) Palaeo methaneseepage history traced by biomarker patterns in a carbonate crust, Nile deep-sea fan (Eastern Mediterranean Sea). Marine Geology, 261, 105-113.

Hanford M, Peeples T (2002) Archaeal tetraether lipids. Applied Biochemistry and Biotechnology, 97, 45-62.

Holm NG, Charlou JL (2001) Initial indications of abiotic formation of hydrocarbons in the Rainbow ultramafic hydrothermal system, Mid-Atlantic Ridge. Earth and Planetary Science Letters, 191, 1-8.

Huber JA, Johnson HP, Butterfield DA, Baross JA (2006) Microbial life in ridge flank crustal fluids. Environmental Microbiology, 8, 88-99.

Ingmanson DE, Dowler MJ (1977) Origins of life, 8, 221-224.

Jungblut AD, Allen MA, Burns BP, Neilan BA (2009) Lipid biomarker analysis of cyanobacteria-dominated microbial mats in meltwater ponds on the McMurdo Ice Shelf, Antarctica. Organic Geochemistry, 40, 258-269. 
Kawamura K, Tannenbaum E, Huizinga BJ, Kaplan IR (1986) Volatile organic acids generated from kerogen during laboratory heating Geochemical Journal, 20, 51-59.

Kengen SWM, Stams AJM (1994) Formation of 1-alanine as a reduced end product in carbohydrate fermentation by the hyperthermophilic archaeon Pyrococcus furiosus. Archives of Microbiology, 161, 168-175.

Knauss KG, Copenhaver SA, Braun RL, Burnham AK (1997) Hydrous pyrolysis of New Albany and Phosphoria Shales: production kinetics of carboxylic acids and light hydrocarbons and interactions between the inorganic and organic chemical systems. Organic Geochemistry, 27, 477-496.

Konn C (2009) Origin of organic compounds in fluids from ultramafic-hosted hydrothermal vents of the Mid-Atlantic Ridge. Ph.D. Thesis, Stockholm University, Stockholm.

Konn C, Charlou JL, Donval JP, Holm NG, Dehairs F, Bouillon S (2009) Hydrocarbons and oxidized organic compounds in hydrothermal fluids from Rainbow and Lost City ultramafic-hosted vents. Chemical Geology, 258, 299-314.

Macleod G, McKeown C, Hall AJ, Russell MJ (1994) Hydrothermal and oceanic pH conditions of possible relevance to the origin of life. Origins of Life and Evolution of Biospheres, 24, 19-41.

Madigan M, Martinko J (2005) Brock Biology of Microorganisms 11th edn, London.

McCollom TM, Ritter G, Simoneit BRT (1999) Lipid Synthesis Under Hydrothermal Conditions by Fischer- Tropsch-Type Reactions. Origins of Life and Evolution of Biospheres, 29, 153-166.

McCollom TM, Seewald JS (2003) Experimental study of the hydrothermal reactivity of organic acids and acid anions: II. Acetic acid, acetate, and valeric acid. Geochimica et Cosmochimica Acta, 67, 3645-3664.

McCollom TM, Seewald JS (2007) Abiotic Synthesis of Organic Compounds in Deep-Sea Hydrothermal Environments. Chemical Reviews, 107, 382-401.

McCollom TM, Seewald JS, Lollar BS, Lacrampe-Couloume G (2006) Isotopic signatures of abiotic organic synthesis under geologic conditions. Geochimica et Cosmochimica Acta, 70, A0407-A0407.

McCollom TM, Seewald JS, Simoneit BRT (2001) Reactivity of monocyclic aromatic compounds under hydrothermal conditions. Geochimica et Cosmochimica Acta, 65, 455468.

McCollom TM, Lollar BS, Lacrampe-Couloume G, Seewald JS (2010) The Influence of Carbon Source on Abiotic Organic Synthesis and Carbon Isotope Fractionation Under Hydrothermal Conditions. Geochimica et Cosmochimica Acta, 74, 2717-2740.

Mevel C (2003) Serpentinization of abyssal peridotites at mid-ocean ridges. Comptes Rendus Geosciences, 335, 825-852.

Moody JB (1976) Serpentinization: a review. Lithos, 9, 125-138.

Nakagawa S, Takai K (2008) Deep-sea vent chemoautotrophs: diversity, biochemistry and ecological significance. FEMS Microbiology Ecology, 65, 1-14.

Neal C, Stanger G (1983) Hydrogen generation from mantle source rocks in Oman. Earth and Planetary Science Letters, 66, 315-320.

Nelson DA, Molton PM, Russell JA, Hallen RT (1984) Application of direct thermal liquefaction for the conversion of cellulosic biomass. Industrial \& Engineering Chemistry Product Research and Development, 23, 471-475. 
Pan C, Geng A, Zhong N, Liu J, Yu L (2009) Kerogen pyrolysis in the presence and absence of water and minerals: Amounts and compositions of bitumen and liquid hydrocarbons. Fuel, 88, 909-919.

Parkes RJ, Webster G, Cragg BA, Weightman AJ, Newberry CJ, Ferdelman TG, Kallmeyer J, Jorgensen BB, Aiello IW, Fry JC (2005) Deep sub-seafloor prokaryotes stimulated at interfaces over geological time. Nature, 436, 390-394.

Peterson AA, Vogel F, Lachance RP, Froling M, Antal MJ, Jr., Tester JW (2008) Thermochemical biofuel production in hydrothermal media: A review of sub- and supercritical water technologies. Energy \& Environmental Science, 1, 32-65.

Pfannkoch E, Whitecavage J, Hoffmann A (2001) Stir Bar Sorptive Extraction: Enhancing Selectivity of the PDMS Phase. Gerstel Application Note, 2/2001.

Pikovskii YI, Chernova TG, Alekseeva TA, Verkhovskaya ZI (2004) Composition and Nature of Hydrocarbons in Modern Serpentinization Areas in the Ocean. Geochemistry International, 42, 971-976.

Potter J, Rankin AH, Treloar PJ (2004) Abiogenic Fischer-Tropsch synthesis of hydrocarbons in alkaline igneous rocks; fluid inclusion, textural and isotopic evidence from the Lovozero complex, N.W. Russia. Lithos, 75, 311-330.

Proskurowski G, Lilley MD, Seewald JS, Fruh-Green GL, Olson EJ, Lupton JE, Sylva SP, Kelley DS (2008) Abiogenic Hydrocarbon Production at Lost City Hydrothermal Field. Science, 319, 604-607.

Roussel EG, Bonavita M-AC, Querellou J, Cragg BA, Webster G, Prieur D, Parkes RJ (2008) Extending the Sub-Sea-Floor Biosphere. Science, 320, 1046.

Rushdi AI, Simoneit BRT (2001) Lipid Formation by Aqueous Fischer-Tropsch-Type Synthesis over a Temperature Range of 100 to $400{ }^{\circ} \mathrm{C}$. Origins of Life and Evolution of Biospheres, 31, 103-118.

Rushdi AI, Simoneit BRT (2004) Condensation Reactions and Formation of Amides, Esters, and Nitriles Under Hydrothermal Conditions. Astrobiology, 4, 211-224.

Seewald JS (2001a) Aqueous geochemistry of low molecular weight hydrocarbons at elevated temperatures and pressures: constraints from mineral buffered laboratory experiments. Geochimica et Cosmochimica Acta, 65, 1641-1664.

Seewald JS (2001b) Model for the origin of carboxylic acids in basinal brines. Geochimica et Cosmochimica Acta, 65, 3779-3789.

Seewald JS, Seyfried JWE, Thornton EC (1990) Organic-rich sediment alteration: an experimental and theoretical study at elevated temperatures and pressures. Applied Geochemistry, 5, 193-209.

Sherwood Lollar B, Westgate TD, Ward JA, Slater GF, Lacrampe-Couloume G (2002) Abiogenic formation of alkanes in the Earth's crust as a minor source for global hydrocarbon reservoirs. Nature, 416, 522-524.

Shock EL (1990) Geochemical constraints on the origin of organic compounds in hydrothermal systems. Origins of Life and Evolution of Biospheres 20, 331-367.

Shock EL (1992) Chapter 5 Chemical environments of submarine hydrothermal systems. Origins of Life and Evolution of Biospheres, 22, 67-107.

Simoneit BRT (1992) Chapter 4 Aqueous organic geochemistry at high temperature/high pressure. Origins of Life and Evolution of Biospheres, 22, 43-65.

Simoneit BRT, Kawka OE, Brault M (1988) Origin of gases and condensates in the Guaymas Basin hydrothermal system (Gulf of California). Chemical Geology, 71, 169-182. 
Takai K, Gamo T, Tsunogai U, Nakayama N, Hirayama H, Nealson KH, Horikoshi K (2004) Geochemical and microbiological evidence for a hydrogen-based, hyperthermophilic subsurface lithoautotrophic microbial ecosystem (HyperSLiME) beneath an active deepsea hydrothermal field. Extremophiles, 8, 269-282.

Takai K, Komatsu T, Inagaki F, Horikoshi K (2001) Distribution of archaea in a black smoker chimney structure. Applied and Environmental Microbiology, 67, 3618-3629.

Takai K, Nunoura T, Ishibashi J-I, Lupton J, Suzuki R, Hamasaki H, Ueno Y, Kawagucci S, Gamo T, Suzuki Y, Hirayama H, Horikoshi K (2008) Variability in the microbial communities and hydrothermal fluid chemistry at the newly discovered Mariner hydrothermal field, southern Lau Basin. Journal of Geophysical Research, 113, G02031.

Testemale D, Argoud R, Geaymond O, Hazemann J-L (2005) High pressure/high temperature cell for x-ray absorption and scattering techniques. Review of scientific instruments, 76, 043905.043901-043905.043905.

Watanabe M, Sato T, Inomata H, Smith RL, Arai K, Kruse A, Dinjus E (2004) Chemical Reactions of $\mathrm{C} 1$ Compounds in Near-Critical and Supercritical Water. Chemical Reviews, 104, 5803-5822.

Whitman WB, Coleman DC, Wiebe WJ (1998) Prokaryotes: The unseen majority. Proceedings of the National Academy of Sciences of the United States of America, 95, 6578-6583.

Zeng X, Birrien J-L, Fouquet Y, Cherkashov G, Jebbar M, Querellou J, Oger P, CambonBonavita M-A, Xiao X, Prieur D (2009) Pyrococcus CH1, an obligate piezophilic hyperthermophile: extending the upper pressure-temperature limits for life. ISME $J, \mathbf{3}$, 873-876. 
Table 1: List of main compounds that could be recovered using current method in hydrothermally-degraded solutions of $P$. abyssi biomass. The table includes compounds that were not detected in the present experiment but that have been reported in hydrothermal fluids from the Rainbow site. Compounds were tentatively identified based on the NIST05 library and their retention time (Rt). For most compounds the analogous series name is given because discrimination between the several isomers could not be achieved. Each sign counts for a compound that was: (+) detected, (-) not detected, (?) may be present but the detection was hampered by coeluting compounds, and (+/-) not repeatable. CTRL is the control experiment.

\begin{tabular}{|c|c|c|c|c|c|c|c|c|c|c|c|}
\hline \multirow[b]{2}{*}{ Compounds } & \multirow[b]{2}{*}{ Formula } & \multirow[b]{2}{*}{ Rt } & \multirow{2}{*}{$\begin{array}{l}\mathrm{CTRL} \\
350^{\circ} \mathrm{C}\end{array}$} & \multirow{2}{*}{$\begin{array}{r}450^{\circ} \mathrm{C} \\
60 \mathrm{~min}\end{array}$} & \multicolumn{6}{|c|}{$350^{\circ} \mathrm{C}$} & \multirow{2}{*}{$\begin{array}{r}200^{\circ} \mathrm{C} \\
60 \mathrm{~min}\end{array}$} \\
\hline & & & & & 720min & $270 \mathrm{~min}$ & $90 \mathrm{~min}$ & $60 \mathrm{~min}$ & $20 \mathrm{~min}$ & $10 \mathrm{~min}$ & \\
\hline n-alkanes & & & - & & - & - & - & - & - & - & - \\
\hline branched alkanes & & & - & 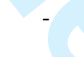 & - & - & - & - & - & - & - \\
\hline cycloalkanes & & & - & & 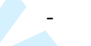 & - & - & - & - & - & - \\
\hline \multicolumn{12}{|l|}{ aromatics } \\
\hline \multicolumn{12}{|l|}{ monocyclic } \\
\hline toluene & $\mathrm{C} 7 \mathrm{H} 8$ & 3.20 & + & + & + & + & + & + & + & + & + \\
\hline alkyl-benzene & $\mathrm{C} 8 \mathrm{H} 10$ & $4.37-4.46$ & - & ++ & + & ++ & + & - & - & - & + \\
\hline styrene & $\mathrm{C} 8 \mathrm{H} 8$ & 4.75 & - & + & + & + & + & + & + & + & - \\
\hline alkyl-benzene & С9H12 & $5.09-5.82$ & - & +++ & + & + & - & + & - & - & - \\
\hline alkyl-benzene & С9H10 & $5.88-6.57$ & - & + & + & ++ & ++ & - & - & - & - \\
\hline alkyl-benzene & С9H8 & 6.71 & - & + & - & - & - & - & - & - & - \\
\hline alkyl-benzene & C10H14 & 7.46 & - & + & - & - & + & - & - & - & - \\
\hline alkyl-benzene & $\mathrm{C} 10 \mathrm{H} 10$ & $8.10-8.20$ & - & ++ & ++ & + & - & - & - & - & - \\
\hline alkyl-benzene & $\mathrm{C} 10 \mathrm{H} 12$ & $7.14-7.87$ & - & + & +++ & ++ & - & - & - & - & - \\
\hline alkyl-benzene & $\mathrm{C} 11 \mathrm{H} 14$ & 10.04 & - & + & - & - & - & - & - & - & - \\
\hline alkyl-benzene & $\mathrm{C} 12 \mathrm{H} 16$ & 10.30 & - & + & \# & - & - & - & - & - & - \\
\hline alkyl-benzene & $\mathrm{C} 13 \mathrm{H} 12$ & 11.03 & - & + & - & - & - & - & - & - & - \\
\hline alkyl-benzene & $\mathrm{C} 15 \mathrm{H} 16$ & 13.44 & - & + & + & - & - & - & - & - & - \\
\hline alkyl-benzene & $\mathrm{C} 16 \mathrm{H} 16$ & $14.56-14.77$ & - & ++ & - & - & - & - & - & - & - \\
\hline \multicolumn{12}{|l|}{ bicyclic } \\
\hline naphtalene / azulene & $\mathrm{C} 10 \mathrm{H} 8$ & 8.48 & - & + & + & + & - & + & + & - & + \\
\hline
\end{tabular}




\begin{tabular}{|c|c|c|}
\hline alkyl-naphtalene, hydro- & $\mathrm{C} 11 \mathrm{H} 14$ & 8.93 \\
\hline alkyl-naphtalene, hydro- & $\mathrm{C} 11 \mathrm{H} 14$ & 9.73 \\
\hline alkyl-naphtalene & $\mathrm{C} 11 \mathrm{H} 12$ & 9.35 \\
\hline alkyl-naphtalene & $\mathrm{C} 11 \mathrm{H} 10$ & $9.77-9.93$ \\
\hline alkyl-naphtalene & $\mathrm{C} 12 \mathrm{H} 12$ & 11.17 \\
\hline \multirow{3}{*}{ alkyl-naphtalene, hydro- } & $\mathrm{C} 12 \mathrm{H} 10$ & 10.71 \\
\hline & $\mathrm{C} 13 \mathrm{H} 18$ & 12.02 \\
\hline & $\mathrm{C} 13 \mathrm{H} 12$ & $11.27-13.02$ \\
\hline & $\mathrm{C} 15 \mathrm{H} 14$ & 14.18 \\
\hline alkyl-naphtalene & $\mathrm{C} 16 \mathrm{H} 12$ & 16.27 \\
\hline \multicolumn{3}{|l|}{ PAHs } \\
\hline acenaphthene & $\mathrm{C} 12 \mathrm{H} 10$ & 11.85 \\
\hline anthracene, hexahydro- & $\mathrm{C} 14 \mathrm{H} 16$ & 15.43 \\
\hline phenanthrene / anthracene & $\mathrm{C} 14 \mathrm{H} 10$ & 14.70 \\
\hline alkyl-phenanthrene & $\mathrm{C} 15 \mathrm{H} 12$ & 15.39 \\
\hline alkyl-phenanthrene & $\mathrm{C} 16 \mathrm{H} 14$ & $16.34-16.78$ \\
\hline pyrene & $\mathrm{C} 16 \mathrm{H} 10$ & 17.44 \\
\hline alkyl-phenanthrene, hydro- & $\mathrm{C} 17 \mathrm{H} 14$ & 17.28 \\
\hline m-terphenyl & $\mathrm{C} 18 \mathrm{H} 14$ & 17.61 \\
\hline \multicolumn{3}{|l|}{ n-alkanoic acids } \\
\hline octanoic Acid & $\mathrm{C} 8 \mathrm{H} 16 \mathrm{O} 2$ & 8.25 \\
\hline nonanoic acid & C9H18O2 & 9.39 \\
\hline decanoic acid & $\mathrm{C} 10 \mathrm{H} 20 \mathrm{O} 2$ & 10.46 \\
\hline dodecanoic acid & $\mathrm{C} 12 \mathrm{H} 24 \mathrm{O} 2$ & 12.47 \\
\hline tetradecanoic acid & $\mathrm{C} 14 \mathrm{H} 28 \mathrm{O} 2$ & 14.33 \\
\hline pentadecanoic acid & $\mathrm{C} 15 \mathrm{H} 30 \mathrm{O} 2$ & 15.16 \\
\hline hexadecanoic acid & $\mathrm{C} 16 \mathrm{H} 32 \mathrm{O} 2$ & 16.01 \\
\hline
\end{tabular}




\section{$\underline{\text { Figure captions }}$}

Figure 1: On the right, schematic view of the internal cell that contains the sample. 1) Top and bottom sapphire pistons with a sealing silicone ring visible on each; 2) sample room between top and bottom pistons ( $2 \mathrm{~cm}$ maximum in our experiments); 3) sapphire tube (partly cut for clarity reasons). The total length of the cell is $85 \mathbf{~ m m}$. The internal diameter is $\mathbf{5} \mathbf{~ m m}$.

On the left, picture of the internal cell before (a) and after a degradation experiment at $350{ }^{\circ} \mathrm{C} / 40 \mathrm{MPa}$ (b) and $200{ }^{\circ} \mathrm{C} / 40 \mathrm{MPa}(\mathrm{c})$. The arrows show the sample room between the two pistons. One can see the evolution of the sample: blurred before degradation, clear after (b) and frothy when treated at low temperature $200{ }^{\circ} \mathrm{C}(\mathrm{c})$. A He bubble is visible in (b).

Figure 2: Total ion current (TIC) traces obtained for the dry blank experiment, which corresponded to the typical TIC for a conditioned Twister ${ }^{\circledR}$; the negative control experiment = brine buffer only (Milli-Q water 18.2 Mohm, 3.5\% $\mathrm{NaCl}, 2.5 \% \mathrm{Na}_{2} \mathrm{~S}$ ); and the duplicated degradation experiment of $P$. abyssi biomass at 350 ${ }^{\circ} \mathrm{C} / 40 \mathrm{MPa} / 10 \mathrm{~min}$. TICs were overlain and are presented here with an offset for clarity. The Twister ${ }^{\circledR}$ signature peaks are highlighted in grey. Major peaks corresponding to phthalates (stars) and polymer additives or derivatives (plain circle) are pointed.

Figure 3: TIC traces obtained for the extracts of the resulting solutions after degradation of $P$. abyssi biomass under various conditions. TIC chromatograms were overlain and are presented here with an offset for clarity. The typical Twister ${ }^{\circledR}$ signature peaks are highlighted in grey and vertical lines point to carboxylic acids (black triangle + number of $\mathrm{C}$ atoms). The locations of alkyl-benzenes, alkyl-BAHs and alkyl-PAHs are indicated on the chromatograms. A representative TIC of the recovered organic composition of the fluids from the Rainbow site in $\mathbf{2 0 0 5}$ has been added for direct comparison.

Figure 4: Evolution of the peak tentatively identified as dodecanoic acid $(\mathrm{Rt}=12.47 \mathrm{~min})$ in the extracts of the hydrothermally-degraded solution of $P$. abyssi biomass at $350{ }^{\circ} \mathrm{C} / 40 \mathrm{MPa}$ for $10,60,90,270$ and 720 min. 
This is a zoom on the 12.35-12.55 min zone of the 5 overlaid TICs. This qualitatively shows the abundance decrease of dodecanoic acid.

Figure 5: Homologous series tentatively identified as alkyl-benzenes among the degradation products of $P$. abyssi after hydrothermal treatment at (a) $450{ }^{\circ} \mathrm{C} / 40 \mathrm{MPa} / 60 \mathrm{~min}$, (b) $350{ }^{\circ} \mathrm{C} / 40 \mathrm{MPa} / 720 \mathrm{~min}$, (c) 350 ${ }^{\circ} \mathrm{C} / 40 \mathrm{MPa} / 10 \mathrm{~min}$. Ion extracted TICs are shown for $\mathrm{m} / \mathrm{z} 106,118,120,130,132$, corresponding to the molecular ion for $\mathrm{C}_{\mathrm{n}} \mathrm{H}_{\mathrm{m}}$ alkyl-benzene with $\mathrm{n}=\mathbf{8 - 1 0}$ and $\mathrm{m}=10$ or 12 . These chromatograms were extracted from the TICs shown in Figure 3.

Figure 6: Isochore for pure water $(\mathrm{d}=0.322 \mathrm{~g} / \mathrm{mL})$. Modified after the NIST database (http://webbook.nist.gov/). The solid curve represents the liquid + vapour coexistence line. The critical points (empty circles) for pure water $\left(\mathrm{CP}_{\text {water }}\right)$ as well as for seawater $\left(\mathrm{CP}_{\text {seawater }}\right)$ are indicated. As salinity increases, the $\mathrm{CP}_{\text {seawater }}$ follows up approximately the isochore (Bischoff \& Pitzer, 1985). The supercritical domain of seawater is represented by the zone in the inside corner of the dotted lines that mark the boundaries. The diamonds represent the three different $\mathrm{T} / \mathrm{P}$ conditions used in our series of experiments.

Figure 7: General structure of the most common archaeal membranes lipids: glycerol dialkyl glycerol tetraethers (GDGTs) (left). Usual structures for $\mathrm{X}$ and $\mathrm{Y}$ for $\boldsymbol{P}$. abyssi consists in $\mathrm{C}_{40} \mathrm{H}_{82}$ isomers and are depicted on the right hand side of the figure.

Figure 8: Distribution of the fatty acids that could be recovered by SBSE coupled to TD-GC-MS in fluids from the Rainbow ultramafic-hosted hydrothermal vent field in 2005 and 2008 as well as after hydrothermal degradation of $P$. abyssi biomass at $40 \mathrm{MPa}$ for different temperatures and times. Temperature and duration of each experiment is given on the $x$ axis. On the $y$ axis, abundances are normalised to the most abundant fatty acid recovered in each experiment taken separately. 


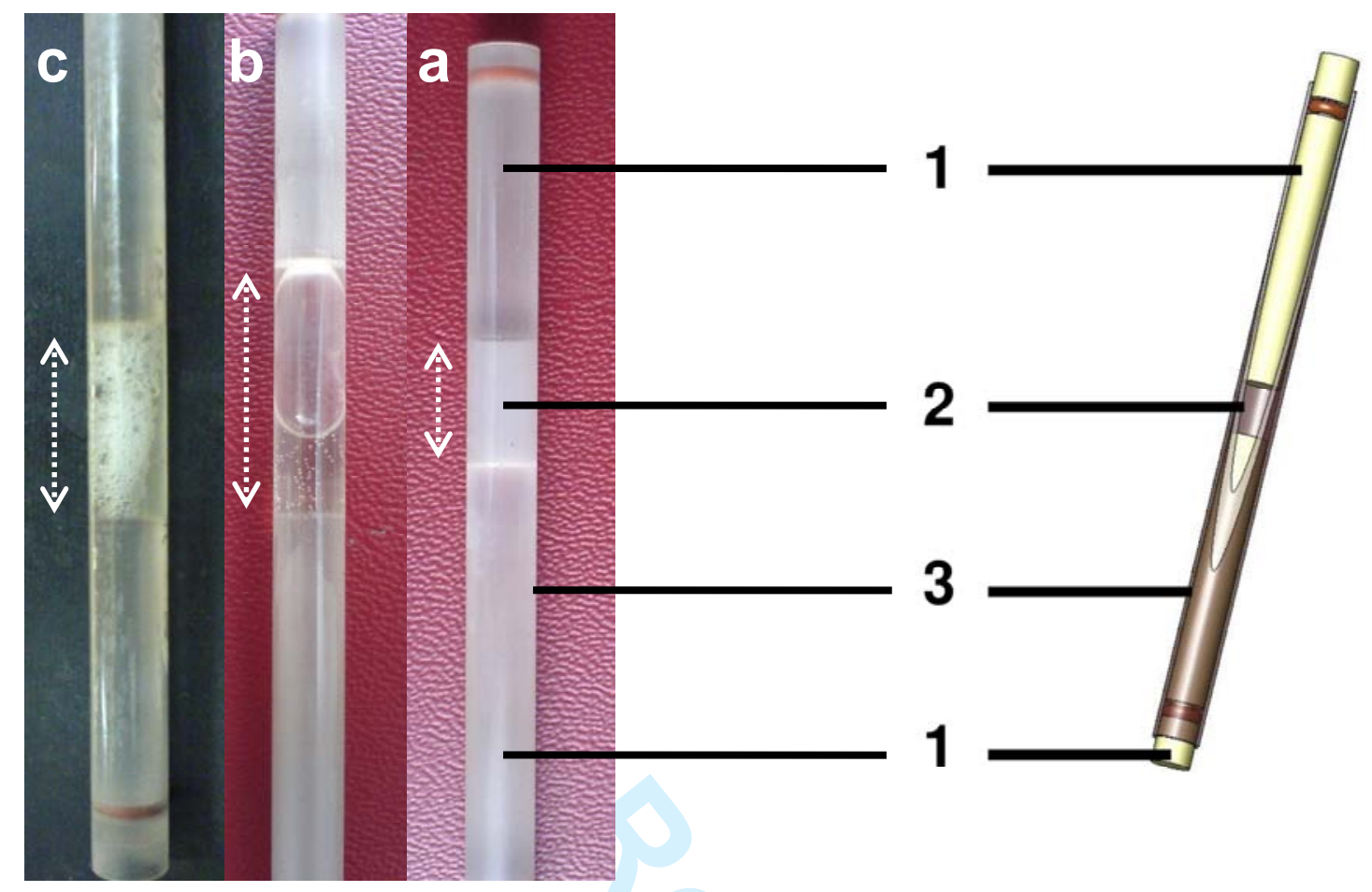




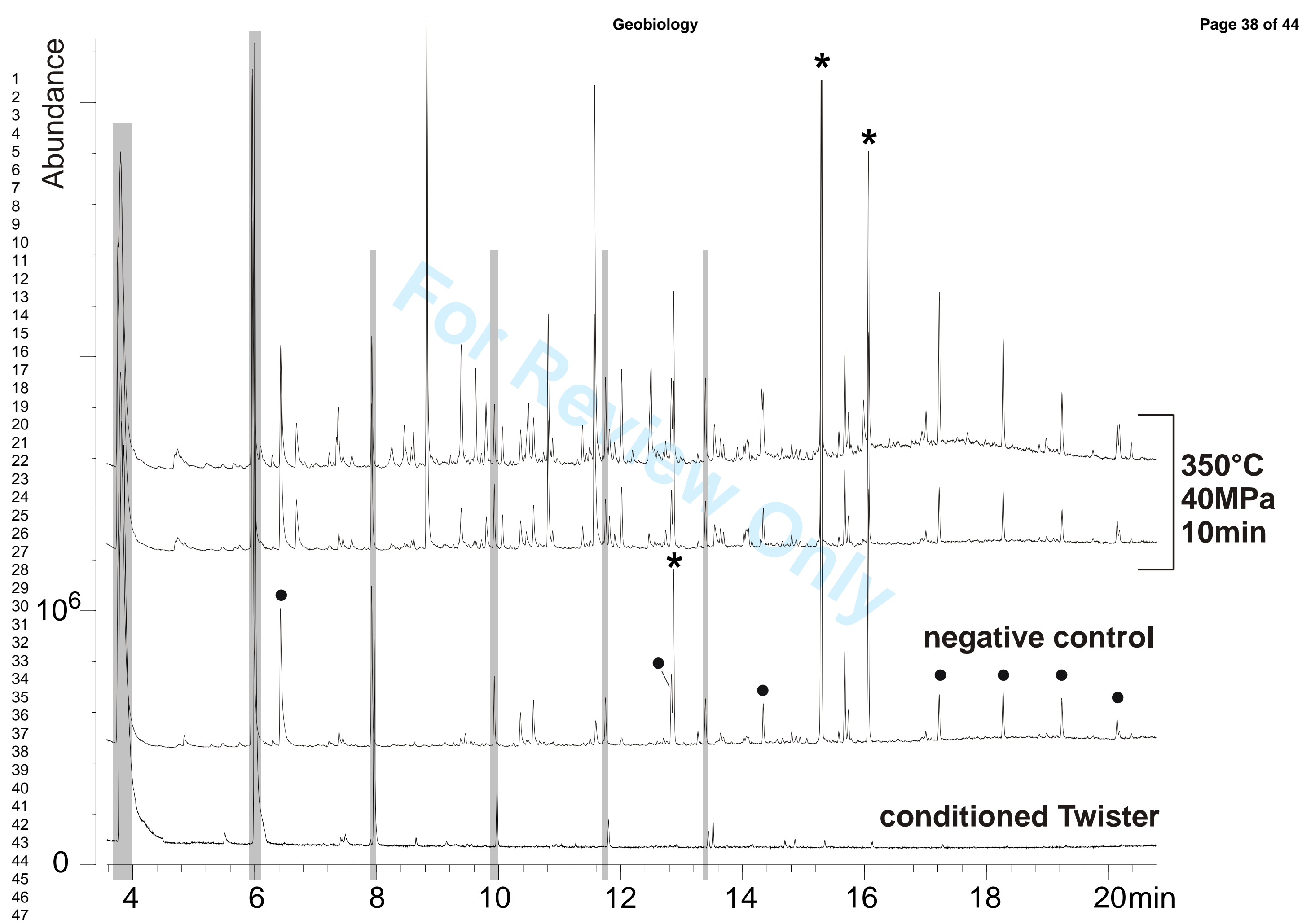




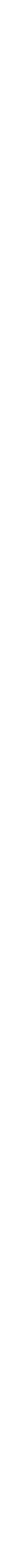




\section{DODECANOIC ACID}

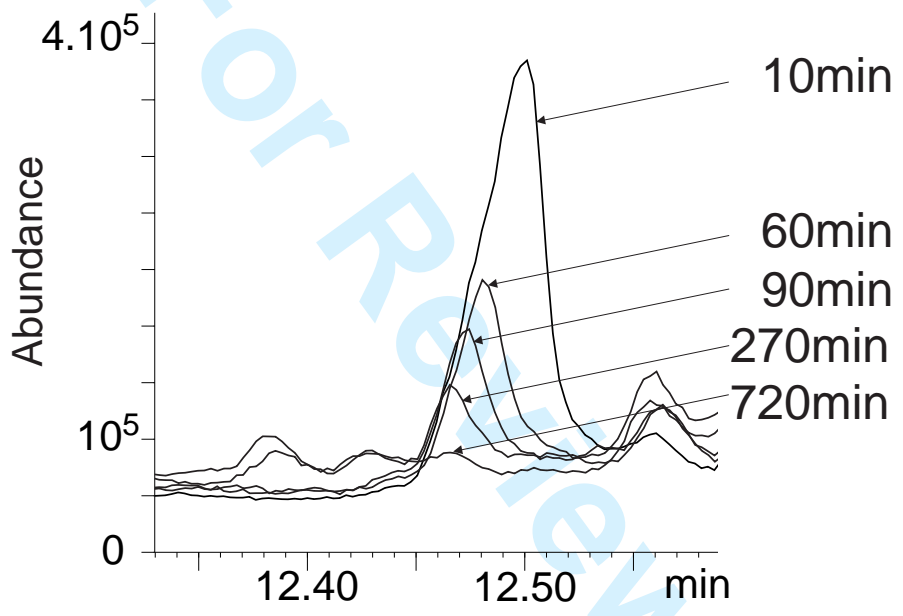




\section{a}
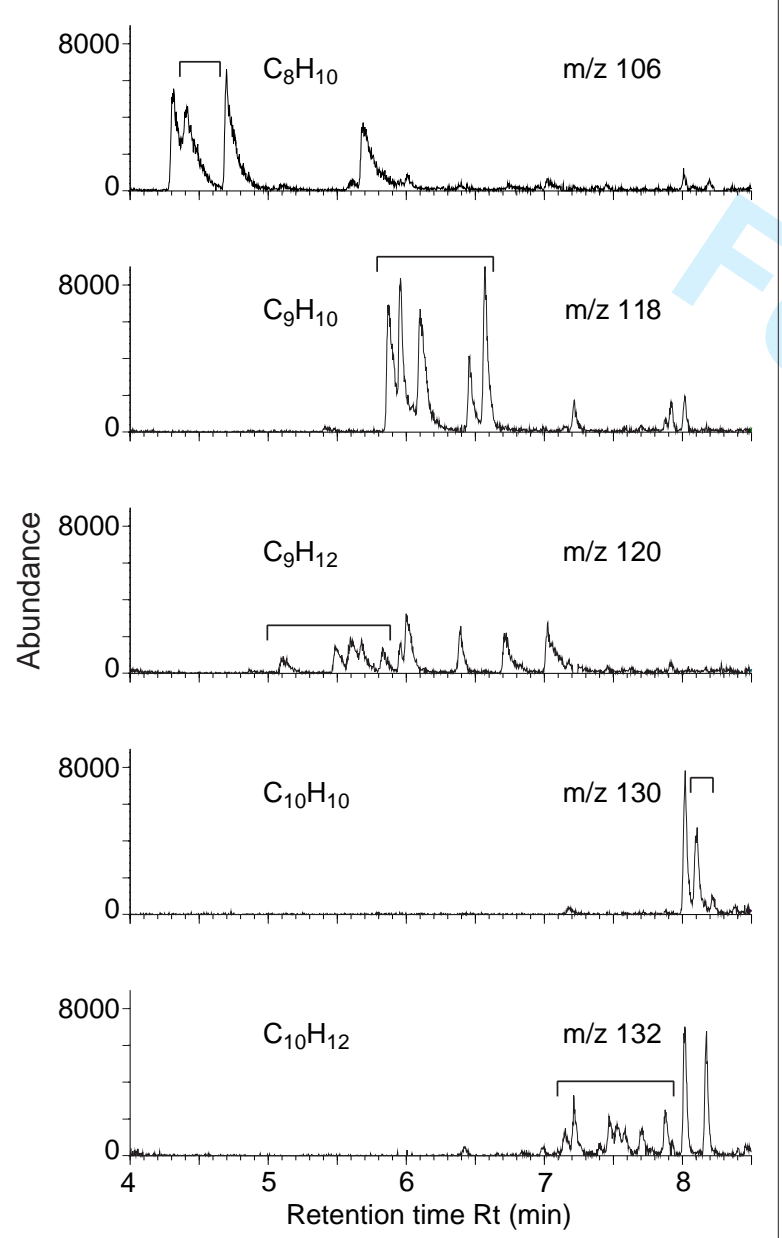

$450^{\circ} \mathrm{C} / 40 \mathrm{MPa} / 60 \mathrm{~min}$

\section{b}
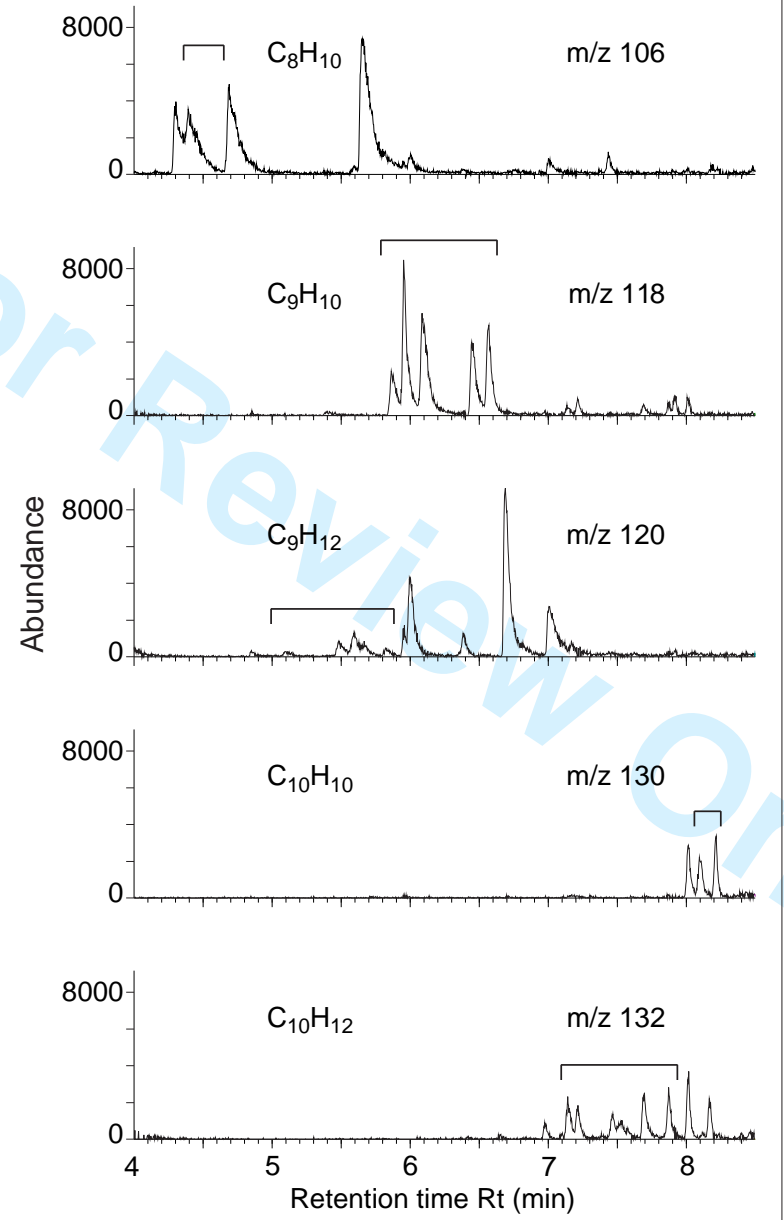

$350^{\circ} \mathrm{C} / 40 \mathrm{MPa} / 720 \mathrm{~min}$

\section{C}

8000

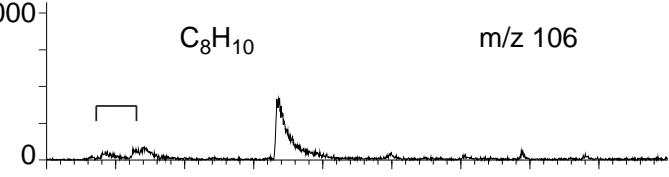

8000
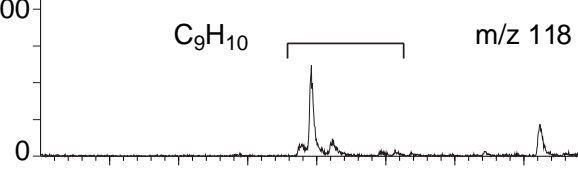

$\mathrm{m} / 2118$

8000

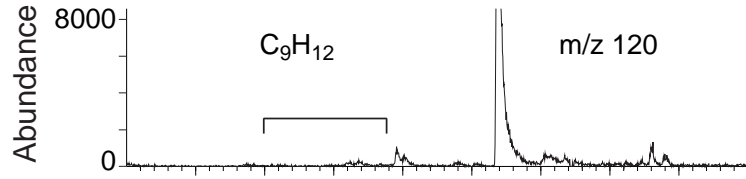

8000

$\mathrm{C}_{10} \mathrm{H}_{10}$

$\mathrm{m} / \mathrm{z} 130$

$\sqcap$

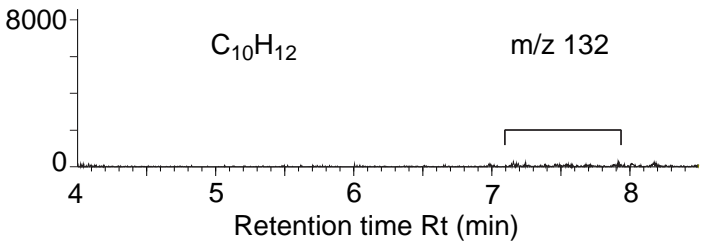

$350^{\circ} \mathrm{C} / 40 \mathrm{MPa} / 10 \mathrm{~min}$ 


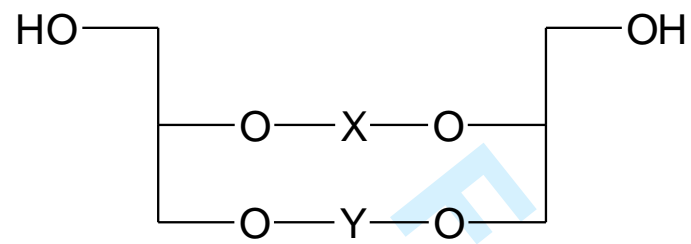

or

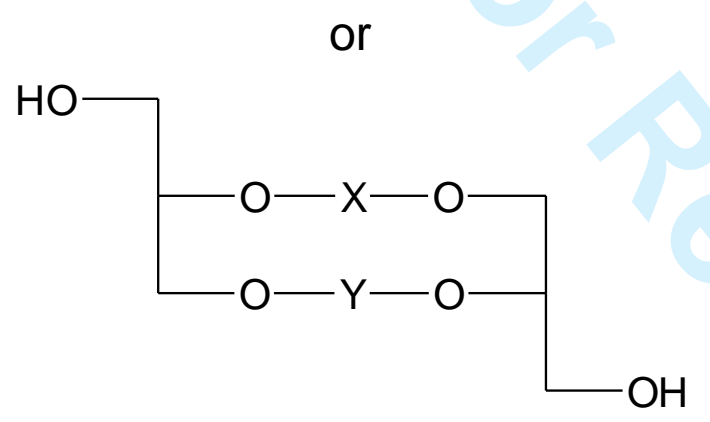

most common structures of $X$ and $Y$ for Pyrococcus

$\mathrm{C}_{40} \mathrm{H}_{82}$ isoprenoids 


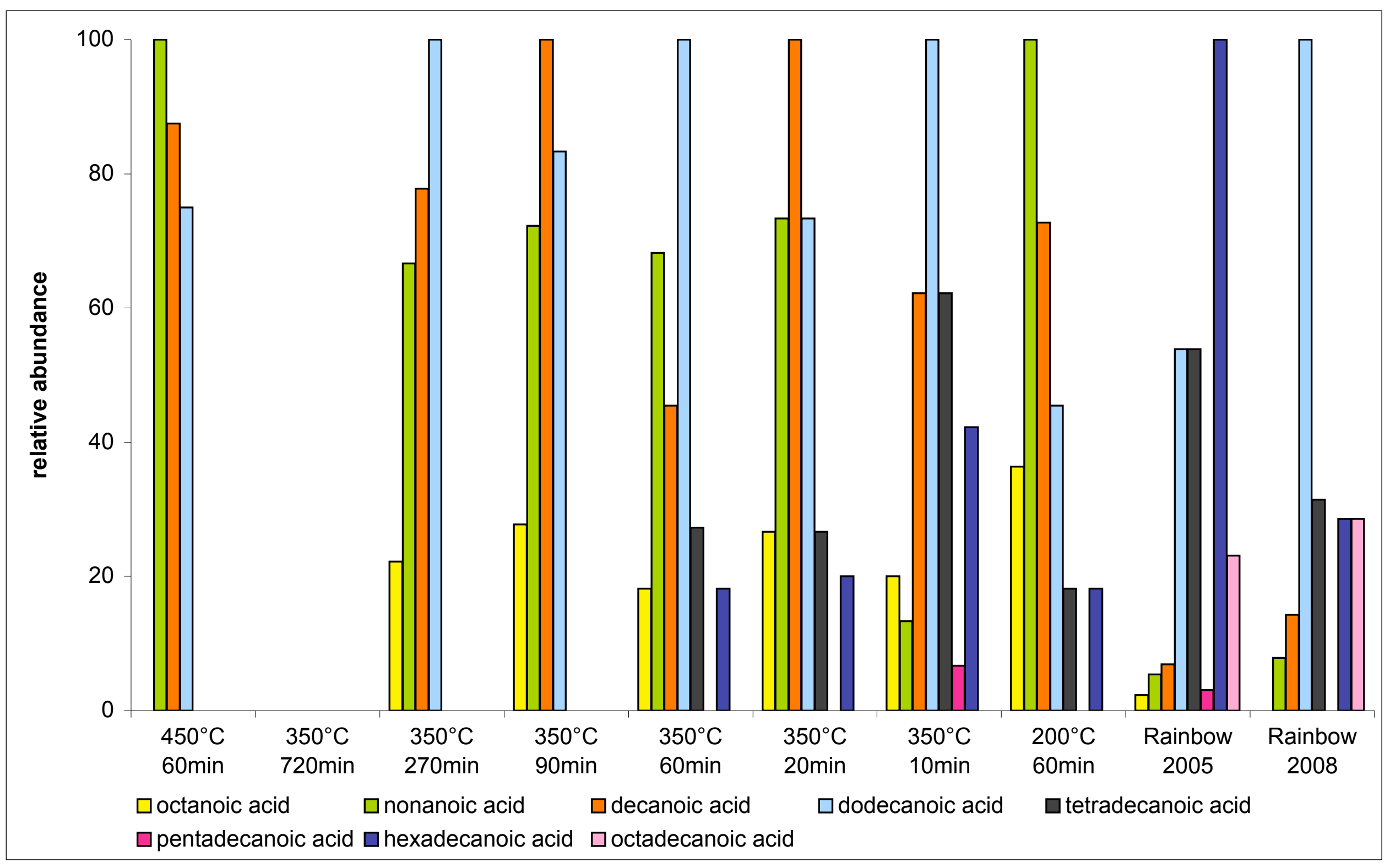

